To Be a Man

\author{
Gina Wohlsdorf \\ Charlottesville, Virginia
}

Bachelor of Arts, Tulane University, 2003

\author{
A thesis presented to the \\ Graduate Faculty of the University of Virginia \\ in candidacy for the degree of \\ Master of Fine Arts in Creative Writing
}

Department of English

University of Virginia

December, 2013 
(C) 2013 Gina Wohlsdorf 


\section{BASIC ECONOMICS}

Your children probably aren't dead. That was the gist of the cops' information.

"We don't have a clear understanding of the situation at this time," said Sergeant Kennison. "You know what we know. Try to be patient."

The shooting started at one o'clock. Word spreads fast in the suburbs, especially when every teenager who's any teenager owns a cell phone. The police set up a checkpoint at an old folk's home that specialized in Alzheimer's - beautiful facility with a topflight staff. They set cookies, coffee and a jug of juice by a wide view of rolling hills. We ignored the snacks. We looked at a hill. Two-hundred yards away, red and blue lights flashed in front of a glass house. I asked Sadie once why Horizon High had so many windows.

"It's a cost savings measure," she told me. "Sunlight reduces the electric bill." Her lopsided smile slammed through my memories like a pickaxe. "But you're asking an Econ teacher. If you'd married Miss Gilbert in Art, she'd have told you they're ravishing."

One o'clock was fifth period, which Sadie had free. Her turn for hall patrol in Wing E: no smoking in the boy's room, no loitering. No mass murder.

That thought got me moving. Kennison stirred his coffee with a cookie fragment and brushed crumbs from his mustache. I stood at the absolute top of my five-foot-seven and spoke at the bottom of my voice. "Give it to me straight." 
His ample eyebrows and fleshy nose made me think of Groucho Marx glasses. "Davey, we got next to nothin'."

"Gimme what's next to the nothing, then." I hit low. "You owe me, Ken."

He didn't. Not really. I'm a grief counselor for Plymouth PD. I knew every cop in that room, and I knew Ken would cave most easily - because I'd helped him through the fall-out of his divorce; because I'd seen him in tears; because we were old Army men, him a sergeant and me a lieutenant, and obeying a superior officer is a tough habit to break. Sadie always said I grow a full foot when I give commands. They work on everybody but her.

Ken tic'ed his neck sideways. We cut through the crowd. I saw Mick Halverson dialing his cell over and over. They'd told us not to do that, but I'd tried, too. Got Sadie's voice mail - sultry, an adolescence of cigarettes: 'I'm not available right now, but if you leave a message ...” I left a message. I couldn't remember what I said. Mick's wife taught French. Sadie liked her.

Ken slid a door to a patio, and I slid it shut behind us. Fresh-stained boards parted for a rock garden that drooled water in a pond. Goldfish laced under floating flowers. Ken said, "You should sit."

"Spill it."

"SWAT found one dead."

I sat. "Male or female?"

"Female."

"Kid or adult?"

"You know better, Davey. No description." 
I threw up the lunch Sadie'd packed me. It splashed in the pond. "Sorry, fishies." “One. One's good. There's fifteen hundred people up there."

"Where'd they find her?"

"Wing E."

"Hallway?"

"Yeah. Sounds like the classrooms stayed secure."

I rocked. "How much longer?"

"No telling. First sweep takes the longest. They wanna be thorough." Ken choked my shoulder to stop the back-and-forth. "You don't gotta freak out yet. I'll let you know when. My word."

He'd tell me himself that Sadie was dead. "Thanks, Ken."

His radio fizzed. "Kenny, where are you? We got a bus."

I was faster. I was the goddamn roadrunner. A bus meant survivors. I joined a throng that surged out the home's front entrance. A yellow box of hope chugged down the hill. So slow, so slow - we all said it, said, "Another one!" when another bus appeared. And another. Another. The head bus found the bottom of the valley, crossed the home's lot, parked cock-eyed and sneezed open. I thought Sadie would be there, front of the line, but she wasn't - some pimply, scrawny man-child. A woman screamed, "Timothy! Timothy!" and the yard became a chorus of names. The next bus parked. The next. Names, embraces, relief as grief, sobs colliding off each other. I searched everywhere. I stood on a wooden bench and scanned. Looked for a crown of blond, listened for a deep cry of 'David.' Only Sadie calls me that. 
It's Dave or Davey or Tomlinson to everybody else. So I knew, after the last of twenty buses docked and disgorged, I knew, even as I kept shouting, my throat getting dry, her name going raspy and dim, I knew, when Ken tried tugging me down, that she wasn't there. "Sadie! Sadie Tomlinson!"

"Davey, I said she ain't here. They took her to the -" "Sadie!"

"She's alive, Dave, she's fine. They took her to the precinct. Come on with me." I clutched at Ken and got down. "Say that again."

"They took -"

"Say she's alive."

"She's alive. She's fine."

"Say it again. Say it "til I say stop."

I never said stop, not the whole ride, and Ken never quit repeating his line, and whatever debt he might have owed me swayed in his favor forever as I nodded along like it was my new favorite tune.

Sadie and I met at a bar. Not supposed to be where you find your future wife, but I was there for a darts tournament, not a hook-up. A robust fogy in a wheelchair beat me by five points. I bought him a beer. He took me to a booth and introduced me to his daughter.

In movies, a guy sees a girl across a crowded room and she's fuzzy and ephemeral. Wasn't like that for us. Sadie shook my hand with a kung-fu grip and cursed 
like a trucker. I was keenly aware of her womanliness; she wore a yellow summer dress with a light sweater, and a diamond sparkled at her cleavage, but she drank three Coronas and said I'd be a better dart thrower if I quit favoring my left foot.

I do appreciate an eye for dart form. "Can’t help it. A chunk of it's missing, courtesy of a pipe bomb in Kosovo."

She didn’t blink - "How much got blown off?" - and drained a bottle like explosions were routine.

Her dad laughed. "Forgive Sadie. She's desensitized to war stories, growing up with me."

"What branch?"

"Marines. Retired a Major."

I quit eye-humping his daughter and examined empty space. It took every scrap of restraint I had not to salute. "Sir, forgive me for being so informal, sir."

Sadie laughed - low, growly. “At ease, jackass. You didn’t answer me. You walk fine."

"I run fine, too. It's minor adjustments that hurt. Plus, the rain."

Sadie looked outside at the downpour and tucked hair behind her ear. I love it when women do that, loved best how she did it. Distracted, a little sad.

The Major covered her free hand. "It'll let up."

She smiled mysteries, and those added to the laugh left me no choice but to get her number and ask her out. We swan dived into bed on our first date, and that's not supposed to be what you do with your future wife, either, but we couldn't help ourselves. 
After, curled together, another storm knocking at the window, I asked why she didn't like the rain.

"The Major was a cop," she said, voice firm and soft at once, a hefty hank of velvet. "A drug dealer he busted got paroled and broke into our house. Went for my room, but I'd snuck out. I was fourteen." I heard her disgust, her shame - guilt that she hadn't been there. "Dad took two in the abdomen and one in the spine. I found him on the front lawn at three a.m."

"And it was raining," I said.

Sadie rolled onto me. "Cats and dogs."

I did my best to earn her like you earn a rank or a medal - hard work and wounds. The miracle was, she didn't want my sweat or my blood. Took a few years to drill that through my head, but we got there.

When the Major shook my hand at the altar, he leaned tight and whispered so only I'd hear, "I'll gut you and make you eat your entrails if you fuck her around." Which is military talk for, "Welcome to the family."

I was out of the car when Ken tapped the breaks to park. I stifled an instinct to run: she didn't need me panicked. The precinct and its stupid landscaping. It didn't bother me when I came to work every morning, but it wasn't often I had to speed-walk a town square to get to my not-dead wife. The struggle to believe her alive, not on a bus but alive, had temporarily obscured a very good question. "Why's she here?"

"I'm not a hundred percent on that." 
"Gimme the percentage you have."

Ken shrugged doubt and shouldered into the building, paving my way so I didn't do something violent to an obstacle. "They're saying she neutralized the shooter."

I tied a knot with my forehead. "Who's 'they'?"

"SWAT. SWAT said, 'Shooter neutralized by civilian Sadie Tomlinson. Escorting Sadie Tomlinson for debrief.' Direct quote.”

"Neutralized him how? Sadie weighs a buck-twenty soaking wet. Unless the shooter was a girl -" But I saw Sadie then, through a conference room window. The sight of her detonated an H-bomb straight through my ribs. I'd never felt anything like it. Her white blouse blazed red. Her blond hair nested flecks of black. Her blue eyes anchored on me, and she knocked her chair over as she stood. I tore the room open. I got my arms around her. My legs gave out, and I took her to the ground wheezing, "Hi, hi, hi."

She dug her nails into the skin of my neck. I pulled back and pawed at the blood. "Is this - did a doctor check you?"

"It's not mine." Her face was bright white and spotted with red, freckle-like dots. Sadie doesn't have freckles.

"A doctor should -"

"We've got a medic en route, Dave," said Lou Cameron, an assistant DA sitting across from Sadie's empty spot.

I kissed her. We're not PDA people, but right then I didn't care. I tried to talk around her lips, tried to make sense, wound up with a word salad of concern. "You're not -", "I love -", "I'm sor -", "How'd you -" 
Sadie climbed me, and we might've gone ahead and done it on the floor if Lou hadn't interrupted. "Guys, we gotta get this statement. Half-life on memories is short."

I tucked her to my chest like a backpack on backwards. "Gee sorry, Lou. Mind if I take one more minute?"

"David, relax." Sadie sounded like herself - like a threat and a lullaby in a single throat. "He's right. I'd like to start forgetting as soon as I can."

I pulled a chair and monkeyed onto it, stuck her in the $\mathrm{V}$ of my legs facing out. I silently dared Lou to object, and he silently declined.

"When did you hear the shot?" Lou said, pen poised on a legal pad.

Sadie flinched. I made my arms a safety harness and said to Ken in the doorway, "Grab the spare shirt in my bottom drawer. And get her a soda, not diet. One with sugar." Ken got set to argue, he wanted to hear this, but he opted to follow orders.

Sadie pulled me tighter around her. "I was on hall duty."

Lou made a note. "You do that every day?"

"Yes."

"Same hour?"

"Yeah. Fifth period. I think he waited for the classrooms to fill -"

"I'm gonna stop you there, Sadie, okay? I need you to stick to what you saw and what you heard. We can speculate later. You're on hall duty, and you hear the shot."

Sadie repeated, robotic: "I'm on hall duty, and I hear the shot."

"What next?"

I pressed to the side of her neck, so I could go with her, and it was like ESP as she talked, as I watched it happen. 
She came around the corner to the east entrance, thinking of firecrackers in toilets, ready to unleash some serious rage on the kids responsible. Instead, there was a girl lying face-up, blood spurting a red Old Faithful from a hole in her chest, impulses in scatter, horizontal jitterbug. A fair-haired boy dressed all in black stood without expression, tac vest loaded in ammo, holding a shotgun sawed so far down the barrel there was hardly a barrel left.

The Major had taken Sadie hunting when she was a kid. She knew guns like she knew Economics. Knew the girl, too - Cara Plimpton; she'd been on Sadie's Academic Olympics team last year. Knew the gunman - Harrison Bane, a boy too pale for handsome, too weird for cool, too quiet for funny. A non-entity, a ghost. Why was he wearing a black beret? Sadie said, "Harrison?" He raised the shotgun, and Sadie did some fast reality math, tornadoed to the right.

The wall disintegrated. Plaster and dust and dead smells and sound. Sadie kicked off her shoes. She was a sprinter in high school and could really move it when she had to, and she had to, for two reasons: one, Harrison followed her, and two, classroom doors began to open.

"Shooter!" Sadie screamed, ping-ponging from one end of the hall to the other, shoving and raving at puzzled teachers, mainlining her voice full of I'm-serious. "Shooter in the hall! Shooter in the hall! Barricade! Barricade!" 
Harrison's next shot came so close that Sadie felt the heat. A locker ten inches to her left caved inward like a rhino had hit it. Shrapnel and buck shot polka-dotted a wide radius. Gabby Halverson peeked out of E220 - "Qu'est-ce qu'il y a -"

“Shooter, Gabby! Shooter!” Sadie shrieked, propelling Gabby inside. "Lock it up! Barricade!"

Harrison was getting frustrated. Sadie could tell, because his shots compressed. She ducked and crouched behind a support column in the middle of the hall. She'd remember it was covered in ads for Student Congress and Key Club. She'd remember wondering, 'What's Key Club?' as she held her head, wood and sheetrock fluttering like snow. Shells clattered loudly to the floor.

The stairs were close, were twenty meters. A sawed-off was awkward to reload. She ran for it.

Bees buzzed past her, small caliber rounds. Handgun. Bullets shattered the bay windows that showcased a gorgeous view of the valley. Thick shards fell with a noise like chimes, but Sadie leaped, took eight stairs at once, landed on her bare feet right before the glass hit the tile. She overbalanced and sliced her hand. Harrison leaned over the banister - high ground, best vantage besides point-blank, so Sadie jumped eight more stairs and made it to ground level, tripping at the bottom, tumbling. She got up in a hurry. Teachers were coming out to investigate. Sadie screamed them inside. "Shooter! Shooter! Barricade!" Shots upstairs as Harrison tried to blow his way in. No-go. Horizon was a new school, opened two years ago - the year Sadie started teaching, the year she married me. All the modern amenities, including hardcore doors and a faculty trained to dive and barricade when they heard the word 'shooter.' 
Sadie ran and yelled - a bloody, skinny Paul Revere - until the whole wing was zipped up tighter than the cheerleaders' sweaters. She picked a spot to stand, dead-center, room to book if she saw legs on the stairs or a shadow in the locker row. Her body did the panicking, knees and wrists and fingers and neck a xylophone of fear, but her head stayed cool, stayed on the next thing.

No legs, no shadow. The fire alarm. It looped a tea-kettle build of whooOOOP whooOOOP.

Sadie wasn't a well-loved teacher. She chose the profession for the summers off, three months of uninterrupted reading, and led the Academic Olympics team to placate administrators. She considered the bulk of her duties, and the bulk of her students, mindnumbingly dull. Basic Economics: shadow prices, opportunity cost, there is no such thing as a free lunch. Her

first day, the captain of the baseball team hit on her - "What's your stance on Statutory?" Sadie had the principal call his parents, and the jock dubbed her 'Ice Queen.' Sadie wrote her nickname under 'Mrs. Tomlinson' every single semester, a point of pride.

Which is why it surprised people that she went back upstairs, using a dank emergency stairwell; that she opened and stepped through a glassless exit, where Harrison might have been waiting, Elmer Fudd-style; that she did these things on nothing more than a hunch, the hunch that Harrison wanted to die - shy, dopey idiot - and he wanted to spread the privilege to as many as possible. The fire alarm would empty wings A through D onto the grounds, twelve hundred pieces of unarmed, unprepared civilian cannon fodder. So he'd be right around this corner here, down this hall, by the door he'd come in, by the lone person he'd managed to kill so far. 
He was. He waded the red pool Cara lay in, slipped and about fell on his ass. Sadie nearly laughed at the failed machismo, at his skinny back heaving impatience, then walking toward his Grand Finale, shoulders high and righteous. She thought of me, apologized, opened a small cupboard, unclipped a chain, and stepped into another hundred meters of locker-lined walls. On her sneaking journey halfway to Harrison, she had a few seconds to wonder if it would hurt when he blew her apart. He pushed on the east door.

And Sadie said, good and loud, the whole wing would hear her, "You pathetic piece of shit."

Harrison's body stiffened - a concrete divider between this dimension and hell. His neck rotated. His face mixed hate and horror.

“C'mon," she said, beckoning. She remembered me talking about amateurs and weapons. Add a little anger and the aim haywires.

Harrison whirled and fired. He took out a ceiling light, unnecessary thanks to endless glass and sunshine. Sadie forced a laugh and ran. Harrison charged her, emitting a manic kind of bugle call, as she raced him to the end of Wing E, to the corner she'd deserted, to the small cupboard with the heavy fire extinguisher she'd unlatched from its hook.

It shouldn't have worked, she'd tell us. She should have dropped it or Harrison should have gotten a shot off or she should have tripped. But Sadie embraced the twentypound tank like an infant, took hold of the nozzle and closed her eyes so Harrison's footsteps plud-plud-plud-plud and his bugle call ba-ga-da-ga-baaah gave her backhanded 
swing a kind of eco-location, sonar accuracy. She played tennis in college. She has a honey of a serve.

She felt the impact up her arm when Harrison's nose smashed to a jigsaw. He dropped the shotgun and fell. Sadie kicked his weapon away and aimed for the soft part of his forehead. A mercy fog descended and didn't let up until bits of brain flew in a sprinkler spray of chunks. Even then, she huddled, watched for twitches - ankles, fingertips, anything - and bashed them motionless. The SWAT team found her there forty-five minutes later, next to a pile of tenderized veal in black assault gear.

"You are the stupidest person in the galaxy," I said. A paramedic sutured Sadie's hand. She'd guzzled two Cokes, and my shirt fit her fine. I had my own chair to give the medic

room, but still draped around her from the side. I spoke directly into her ear. "You're stupider than whatever worms eat."

Lou turned his eighth page. "Was Harrison Bane in your class?"

"Yeah," Sadie said. Tears leaked every few minutes, but they didn’t disrupt her voice. "Quiet kid."

I couldn't get the image out of my mind. Sadie drawing shotgun fire. "What were you thinking?"

Lou said, "Dave, zip the lip or you're -"

"I wasn't," Sadie said. "I didn't think. I just did it." Her eyes poured faster. 
I swiped my palms across her cheeks and chin, wiped her nose with my knuckle. "Okay, baby. Okay. Look at me, it's over. I'm proud of you. I was being an asshole."

The EMT snipped thread and asked, "Are you cold?"

Sadie nodded. I ripped my jacket off.

The medic stood. He was a mobile Empire State Building. I hadn't noticed his height when he came in. "She should take it easy the next few days," he told me.

"I'm right here," Sadie grumbled.

He grinned at her. "You should take it easy." I was used to guys grinning at my wife that way.

Didn't mean I liked it. "Sure, buddy. We'll put off the marathon. Thanks."

Sadie rolled her eyes while the medic hauled out his equipment. The door clicked shut. "Subtle, David."

"So’s he."

Lou tapped the tape recorder. "We're as good as done, I promise."

Sadie and I made identical go-ahead signals and smiled when we realized it.

"Why didn't you evacuate when you heard SWAT clearing the classrooms?"

"I didn't hear them. That second blast made me damn near deaf for an hour. My

ears are still ringing."

"Why didn't you -"

"What is this?" I said. "Are you looking for a man on the Grassy Knoll?"

Sadie scooted back to my lap. "Let him finish so we can get the fuck out of here."

Her curse words were coming back. That appeased me for a while.

"Why didn't you notify the other teachers the threat was over?" 
She hesitated, shifted. "I needed to be sure he was dead."

"Is that why you fought when the officers tried to remove you?"

"Yes."

"Last question, then you can go." Lou put down his pen and reached across the table. "May I please shake the hand of the bravest woman I've ever met?"

She fumbled for my hand instead. "Take me home."

Plymouth, Minnesota's won awards for being the \#1 best town in America and isn't shy about bragging it up. While we drove Main's mile of banners, I wondered if a school shooting meant they'd revoke the title. Our address hopped the city line to Wayzata, far enough from Sadie's work and mine to let us forget the job when we left for the day. The property was a gift from the Major, three acres in a clutch of forest, a pond we skated on in winter. We built a two bedroom house with six years of my Army money and our bare hands. It hugged a rock wall and sat three stories high. Big garden, window boxes, covered porch, attic. Garlands of Sadie's flowers hung from every square of glass. We knew it'd be a nightmare to heat the high ceilings, so we put fireplaces in the living room, dining room, master bedroom and bath. The guest room was a guest room; we didn't want kids.

Sadie's shaking lessened the moment she crossed the threshold, but in spite of this, and in spite of it being a pretty temperate October night, I hurried to light every fireplace, telling Sadie I'd fix her something to eat.

She examined her stitches. "I need a bath. There's - my hair has ...." I'd forgotten. Maybe she thought I didn't know what the black flecks were. She was trying to 
tell me, but she got stuck, stuttered, "b-b-b-" until she dropped. She made horrible sounds.

“It's okay. It's okay, Sugar.” I picked her up, but she didn't want to be carried, insisted on blundering beside me. I lit the fire and drew a bath. Sadie winced as she shrugged out of her clothes.

"What hurts?"

She held her left arm in a triangle. "I must've strained it."

I imagined her swinging twenty pounds of metal into a running boy's nose. 'I'll cook something."

"No, come in with me."

"Sade, you've gotta eat."

"I will. After. Please?"

Naked and 'please.' Deadly. We took our usual positions, sharing the built-in seat, letting the whirlpool jets pass over us. Hot froth peppered our sinuses. I put a hand on her left shoulder and kneaded. She groaned - quiet groan.

"Keep going?"

She nodded.

I worked through muscle fibers strand by strand, taking my time. We had time. She'd earned us who knew how much more time today. My other hand strayed elsewhere. Sadie searched for me under the water. I hooked her uninjured arm around the back of my neck. "It's about you tonight, okay?" I made her answer all vowels. When I got down to business - the real business, the fake freckles and the rubbery nubs of brain in her hair - she was a pliant creature moaning at my touch. And I teared up, no fighting 
it, tried to hide my own burbling nervous breakdown as I dried her, erection thick enough to chop trees, my limbs shivering water droplets into the towel, but Sadie knew. Of course Sadie knew. Marriage is cutting your heart out for someone else to guard, and she's a fierce guard. Obviously.

"David. David, slow down."

Patted every inch of her, wiped death away. Held it together until she yanked my head straight. I kissed her like a film in fast-forward, bucked her into the wall and held her up. I was featherweight champ in the Army. I'm short, but I'm strong. I wanted to be tender, gradual, but I was crying and she was crying, and we were fucking like my dick was a defibrillator and I could shock life back into her, though she wasn't dead, the shooter was dead. She'd killed him. My baby bludgeoned him to hellfire, and the wall wouldn't work for what I needed. I pulled out and carried her to bed, where I got proof of life in each airy scream.

I woke right before the alarm. When the gears click inside, preparing their soft buzz, it sounds a lot like a gun cocking. Most mornings, I can thwack snooze before the first noise happens. That morning, I beat the noise and pulled the plug.

She'd made a pillow of my stomach. My navel was a cup for her breath. No one would expect us at work today, but my legs still twitched for their miles. I shuffled from under her, gave her a real pillow to cuddle, squatted there a second, watched her sleep. A bad dream played behind her eyelids. The angle of her mouth betrayed a chase, a 
quicksand getaway. Sadie had enough material for nightmares. She still found the Major mostly dead on the lawn whenever it rained at night.

I pictured Harrison Bane. He was a shadow-man, I'd only heard description. I began with his face. I turned the shadow tequila sunrise colors, then did limbs. I disassembled him like a pup tent. Torso was last. Torso was tougher, so I brought a knife with me, and he begged. Sadie whinnied at a bad turn of events. I sang her some Bob Dylan. Best thing about Bob Dylan, you don't need a singing voice for his songs. She unclenched, forehead smooth as a window. I kissed the surface and got dressed.

It's pussy to love someone like that, my buddies said. Army guys, hard drinkers, fist fighters, love 'ers and leave 'ers - they learned fast to shut that shit up in my presence. I was raised by fosters, I witnessed my best friend's death by machine gun, and I treated women like carnival rides. Sadie was my silk cocoon. I came out a moth, but she didn't mind. She became the bare bulb I flew around. It's pussy to love someone like that, so I'm a pussy and I'm proud. I don't have anything else.

I stretched by the front door, thinking dark woods sounded right today, but when I opened up to the porch, a pop of white light blinded me. I didn't have a weapon, which was lucky. My memory screamed, 'Flash grenade!' I'd have shot for sure.

"Is she injured?"

"Is she in shock?"

"Did she have martial arts training?"

"Did you teach her self-defense?"

"Does she have a history of violence?"

"Do you have a history of violence?" 
I said words they couldn't print and tripped backwards over my own feet. I shut them to the lawn where barking dogs should stay. Fantastic. Exactly what she needed. I did reconnaissance - forty-two messages in home voice mail, five news vans on our property, and thank the Great Whoever, Sadie still asleep.

I dialed with a force that fit a history of violence.

"Dispatch, this is -"

“Carla, it's Dave Tomlinson. Can you give me the lead officer on shift, please?"

"Dave, how is she?"

I wouldn't yell. I liked Carla. "She's fine. She's snoozing. Is it Schmitt this morning?"

"Yep, sure is. I'll patch you. Give her my best."

"Will do."

I didn't like Schmitt, but I could fake it for one conversation. I gave him the rundown. He promised action. I stomped on the treadmill for four miles until I heard a flump at the doorstep.

Checking their distance: four vans and a baker's dozen camera-toting, coffeesipping jackals waited just over our property line. Brian Knowles, our paperboy, was getting interviewed by the more desperate reporters, while those with standards faked indifference and listened closely. I watched the drama through my rifle scope, dawn graying the sky, highlighting the powdered faces that made homes for my cross-hairs. I suppose I could've detached the scope from the gun.

Sadie gaped from our welcome mat, a close-up of blood-freckles, tear tracks and huge, bleary fear. I procrastinated coffee because the smell would wake her, rushed 
through a shower and changed. She'd kicked the covers off. I replaced them, noted a black-blue tint to her shoulder. In the living room, I claimed my chair like I would any morning.

"HERO," said the headline. This wasn't the local paper. This was the New York Times. "Economics teacher Sadie Tomlinson went to work yesterday occupied with thoughts of quizzes and midterms. She left partially deaf and forever a legend." Thetruth-lite, continued on page seven.

"Great, they got my zombie side." I flapped the story shut. Sadie wore jeans and a t-shirt, the Wile E. Coyote slippers I gave her for Christmas as a joke. She sifted for the crossword puzzle.

"I'll make breakfast. You want waffles, eggs?"

"It's my turn."

I headed for the kitchen. "Not today."

She caught me by my back pockets. "Could we act normal?" Nosed between my shoulder blades. "Pretend it's Saturday?"

Saturday meant cherry nut muffins. Sadie made them and the coffee. She did the crossword, cursing at it and erasing while I read students' and colleagues' glowing opinions of her that were almost uniformly bull. "Committed to her work," "Has a smile for everybody," "Totally the nicest person I've ever met." Cara Plimpton got one paragraph -4.0 , wanted to be a vet.

I ditched the front section for sports. "How's your arm?"

"Sore."

"Did the medic check it at all?" 
"It's a strain." She went for a refill, though her cup still piped smoke. "You should work on the shelves today. You could finish."

The fact that her denial was textbook did nothing for my worry. I was putting shelves into the walls of the study. They were nowhere near done. "What'll you do?"

Stupid question. Sadie was buried in a book by nine. I left her in the living room and pounded nails, sanded boards. I turned to grab a drill and saw her in the desk chair, twirling the seat with a toe. She hated noise while she read, just like I hated missing my morning run. Hours like that, then a break for lunch. She followed when I made sandwiches and followed me back to the study after. Sadie was many things, but a clinger wasn't one of them. I could remember the same sentiment, the visceral need for other warm bodies nearby. In war, that's not a tall order. In marriage, it shouldn't be either.

Our cells rang and rang. We checked the numbers but didn't answer. 'Til she answered.

"Hey, Dad. No. Yes. Fine, no. I think I strained my shoulder."

I smiled. Any Saturday.

"I'm not sure yet. Yeah, if y-. Seven's fine." She laughed and hung up. "Such a chatty son of a bitch."

“Coming for dinner?"

"Bringing dinner." She tapped buttons. "The station keeps calling me."

"Me, too."

"What do they want?"

Sadie rarely sounded small. I went and sat with her on the sofa. "A walk-through, probably. Have you show them what happened and where." 
Sadie never curled up to me like a kid trying to hide. "They can't make me, can they?"

Damn it. "Yeah, baby. They can. They'd get a subpoena."

"Will you be there?"

"They'd have to taser me to keep me away."

"Not funny."

"Not kidding."

"I should've ..." She got two good grips on my shirt.

"Should've what? Huh?"

"It should've been me."

I felt relief so acute it was painful. Finally, something I had a speech for. "It's not wrong to be glad you're alive. I'm glad you're alive. It doesn't mean we're glad Cara's dead. Those're two different things."

Sadie thrashed against my ribs - part disagreement, part an attempt to burrow inside. I got my own good grip and held her.

While Sadie set the table, I dialed Lou Cameron's extension at work and stated the terms. "We do it once, in and out. Ten minutes, tops. I'll be timing it."

Lou tried his one-of-the-guys voice. "Davey, I don't want to put her through -"

“I know you don't, but you're still going to do it, aren't you?"

"It's procedure." 
Boxing wisdom states that when the head is guarded, you go for the gut. "Sadie made you strawberry pie when your mother died, because she remembered you liked it at the potluck.” Ding-ding! TKO! "Ten minutes.”

I could hear him nodding. "Ten minutes." He rattled off where to meet and when. The doorbell rang. I said goodbye, answered the door, and said hello.

“The hyenas have your Army record." The Major handed me bags of Chinese.

"What'd they ask you?"

"Whether you beat my daughter."

"Charming."

The Major got a hell of a settlement out of the city. A flunky in the Records Department sold officers' addresses, and Internal Affairs couldn't find a swatch of cloth to cover its ass. Which meant the Major sent Sadie to college, hired a physical therapist and chauffer, and installed a home gym that pretty much made me faint the first time I saw it. Which in turn meant the Major - with his crew cut and Superman jaw - looked like he'd leap from his wheelchair any second and bench-press the sofa for fun.

Especially when he was angry. "How is she?"

Sadie hitched a hip on the dining room wall. "She's fine, Dad."

I used to think it was hilarious how the Major transformed in Sadie's presence, genuine happiness on features meant to scowl. Until I realized I do it, too.

"You're lying to me." The Major wheeled close for his kiss on the cheek. "Yep." She pecked.

I unpacked. "Sir, were you intending to feed a regiment?" 
"Figured you kids wouldn't be grocery-bound. If you need any errands run, let me know. Keaton gets bored waxing the car."

Sadie divided rice, poured orange chicken on mine, beef and broccoli on the Major's, kung pao for herself. "I'm not letting this make me a prisoner."

'Not what I'm saying, Sadie Mae. I'm saying if you need to lay low and recover, you damn well lay low and recover."

She split a pair of chopsticks like enemy bones. "Why is everyone treating me like a goddamn porcelain doll? I killed that kid." Her body seemed to jolt. Gone-over shock resurfaced. I tried to touch her, but she shied from me, picked up silverware and faked fine. The Major baked her with scrutiny for several seconds. Sadie said, "What?"

The Major placed his right elbow on the table and hitched his sleeve. "Remember this?" A tattoo of five doves in flight covered his wrist.

"That's not -"

"You'll kindly listen to this story again, my dear."

I don't like contradicting Sadie's dad. It goes against the molten core of my moral code, but - "If she doesn't want to hear it, sir, I suggest you save it for another day." The Major wasn't used to insubordination, either, and told me so with a look.

Sadie laughed - miserably, but she laughed. And budged her chair closer to mine. "Christ, guys. Put 'em away. The tape measure's not long enough."

We all laughed, then. Wholesome family penis humor. I put my arm around her. Battle stories don't dress up. The Major took a breath that reached a little deeper than normal and spat facts: “A sniper up a tree put four in my friend's chest. Pete Rathjen. We were in retreat, double-timing, but Peteybird was our squad's pet. Could 
make you laugh 'til you cried." The Major's left hand palmed flat to the table, but it signaled 'double-time', then 'rear guard.' I wondered if the pores of that hand felt thick jungle humidity and the wet sting of slouching leaves. "So I picked him up. He was a flyweight like your husband there, one-sixty at the outside. I ran fast enough to win a goddamn Olympic gold medal. They gave me a Silver Star. Why d'you suppose I got this tattoo?"

Sadie squeezed my knee. I said, "Sir -"

"Because five other boys died giving me cover. They went one to my right, one to my left, one to my rear, and if a man fell, another took his place. Two miles. Pete Rathjen lived to be fifty-nine. Cancer got him. I was there when he went. Last thing he did in this mortal coil was touch the doves and say, 'I hate collateral damage.'”

"That's enough, Major."

Sadie muttered, "Let him talk."

"You're shaking again."

"I'm cold."

I gave her my sweatshirt. And I lit the fireplace.

The Major dipped an egg roll in hot mustard, stirred like the sauce was a magic fountain where the past reflected and made sense. 'People like the word 'hero.' Gives 'em a nice warm fuzzy. But the hidden definition of 'hero' is somebody who doesn't sleep." Sadie guarded his heart, too, like a lioness. What she'd needed in return was our protection, and we'd failed her. The Major knew this like I knew it. He was saying he was sorry. "We're all porcelain dolls underneath. Dave and I have training on our side. 
You minimized casualties, performed recon, improvised a weapon, and delivered a kill strike wearing heels and a skirt."

"I kicked off the heels," Sadie corrected.

The Major and I burst out laughing. Sadie smiled.

"Papers get it wrong," the Major said. "Count on it. They're working with the wrong definitions. You do whatever it takes, Sadie Mae. You lean as hard as you want on that boy." The Major pointed at me. "And you, Lieutenant, bear up."

Against the table, palm-down, I signaled 'all-clear'. The Major saw, but for Sadie's sake I answered out loud. "Yes, sir."

We pulled into the old folks' home the next day at noon. I told Sadie about Ken and the crowd, the patio and the fish pond. I said I hoped koi weren't allergic to vomit. Lou stood by an official city SUV. Kennison had tagged along, and so had a stranger in a suit. "Shit."

"What is it?"

"Lawyer. He's got the requisite gavel up his ass."

We both connected a lawyer to the morning's paper, which said Cara's family intended to sue the Plymouth school system for negligence. "Where's that pond? I need to throw up." She'd turned china white.

"Sadie, listen. This is the last time you have to tell it. The reporters can go to hell. But this is the law." She really did look sick. "I can get it postponed if -" "No. Let's go." The Major possessed her face. 
Lou and Ken met our approach with appropriate shame. "DA told us to cooperate," Lou said, followed by, "Sadie and Dave Tomlinson, Bill Spell."

"William," said the suit, offering me his manicure. "Pleasure." I squeezed to show him I could snap. Spell was a gaunt, fey forty-something. I figured he'd swung a lot of golf clubs but not a single fist. I put myself between Sadie and Spell in the SUV, but he still tried. "I hear you were acquainted with Cara."

"Don't talk, Sadie." For once, a direct order did the trick. She took my hand.

Guards waved Kennison past check-in, while Lou said from the passenger seat, "As discussed, Mr. Spell, you are here in an observational capacity only."

"Just making conversation."

"Well, don't," I said. "I'm a tad protective."

"Yes, I hear you almost went Section 8 after your buddy died. You got counseling, correct? Found a new career?"

Sadie used her nails and made moons on my fingers. My ego went out the window, fluttering like loose paper.

Spell gave up.

Horizon had an infinity of yellow lines ordering 'Do Not Cross' by the main entrance. We drove over sidewalks and stopped beside the flag flying half-mast. Sadie moved like an unoiled machine as she got out of the car. Kennison used a key. I was losing circulation in my fingers.

"Why are we going in here?" Sadie said. 
Lou answered. "Avoids the broken glass." He gestured to lead the way. Sadie and I stepped forward. "Dave, it'd be better -" I waited. He'd have to tell me. "Sadie should take us through.”

Porcelain faked bulletproof for our audience. She dropped my hand and marched.

We had to hurry to keep up. I keyed my watch's countdown when she struck for Wing E with jet fuel in her knees, her footsteps a cadence: A little bird with a little bill/Was sittin' on my windowsill/I lured him in with a piece of bread/And then I smashed his little head. Stink of a slaughterhouse, getting nearer. Sadie's breathing matched her pace, then outpaced it. She halted so suddenly, I almost bumped into her.

“Sade?" I said.

She didn't seem to hear. To our left was the door she'd snuck through. 'Emergency Only - Alarm Will Sound.' And here was the alarm, handle still hanging. The compartment for the fire extinguisher stood empty, with an iron chain dangling like a lifeline to dead air. Beneath this, a black-maroon Rorschach leered chicklet bits of bone and oxidized brain matter. But Sadie wasn't looking at the corner where she'd killed him. She was looking at another stain straight ahead, in the prism of hallway windows, reflective metal lockers. A quart of dried-up red on the floor. Sadie made a choking sound.

“You were here?” Lou asked.

Spell sniped, "How about she tells us?"

"I was there." Sadie pointed. She laughed. "Cara looked like a fish."

I was not a fan of that laugh. "Hey -" 
"Where's 'there'?” Lou glared at me.

Sadie went to Cara's blood and paused, went left to the corner she'd turned. "Here."

Lou took notes. "What next, Sadie?"

"I ran." She walked. The corridor appeared endless, but the meters were a perfect hundred. The track team ran halls in winter. "Mr. Lee, he -" Sadie beat a closed classroom door. "Shooter!" She shook her head once, hard, like the memory would fall out of her ear and she could hand it over. "Shooter, Frank! Shooter in the hall!" Sadie ran to the opposite wall, to an open door, and clapped it closed. Only the lawyers were confused. Kennison and I chased her to a mangled locker, where Sadie hollered and careened forward, feeling bygone heat and blind shrapnel. She treated my touch like a bullet and cringed, cringed - behind a pillar that looked like an apple core ravaged by worms. She frowned at a Key Club ad that wasn't there anymore. I knelt in front of her, but she didn't see me.

“Guys, that's it!” I hollered, as Lou and Spell flapped gums at Ken, who glowered at them. "Sadie? Sugar? That's plenty, Sadie. You did great. Come on back." Her body tweaked at some phantom sound. The shells - tatta-tat. It's not a good idea to fight the memories at full-strength, but she was hyperventilating, ducking from ghost tufts of disgorged pillar. She was estimating distance and odds of survival to a set of stairs that no longer ended in smooth tile but in chunks of glass that twinkled on the landing like Northern Lights. I grabbed her chin and screamed at full combat volume, "SADIE!" 
It only half-worked. Her body slumped, adrenal overload, but she still tried to crawl for her life. I trapped her. She wrestled, weak, yelling relentlessly, "Shooter! Shooter!" Lou and Spell looked down on us in revulsion.

"Fuck off," I said. "Go lick a blood stain, you fucking ghouls."

They left us there. Sadie's warning cries gradually loosened to what lay underneath. I was a safe cage, a rocking chair.

"I'm sorry, David, I'm sorry, I'm so sorry."

"It's okay, it's okay, you did good, you did a good thing."

Her face tilted and begged that I read something she couldn't say out loud something with claws and teeth, something tearing its way out of her.

My watch beeped. Sadie jumped, and her body wilted further. I tried to carry her. She didn't allow it. Her knees folded, and I took most of her weight.

Ken and the lawyers stood by Cara's blood. "Sadie," said Lou, "just one -" "No," I said.

"Where were you standing?"

"She answered that."

Ken gawked at the floor like it was a Magic Eye poster. "Davey, it don't add up." Lou blocked me; I almost admired the balls. "Sadie, show me where you stood. Please, okay?" Lou's tone belonged on a pre-school cartoon.

Sadie locked her legs and snarled, "I beat his brains in." “Yes," Spell said, “we know. The dead tell no tales, right?" She left my hold and pivoted and shoved him. Shock stupefied me. Sadie didn't do things like that. Sadie was practical. My mind grasped for what I'd missed, but Spell turned rabid and red-faced. 
"Whose footprints are these?" he said, pointing at the floor. "Size nine. Cara was size five." Spell's thin mask of patience disintegrated. He grabbed Sadie's bad arm and wrenched her toward the prints. She yelped.

My vision went silver. I don't remember moving. Next I knew, I had him backed against sunlight. I saw hornet's nest drywall. I saw a larynx close to cracking. I saw Harrison Bane.

Ken tried. "Davey, let him go."

"It makes perfect sense," Lou said. His pen scratched in a fury. "She stepped in the puddle first. She came further than she thought, got in the blood, then ran."

“David." Sadie's breath on my neck.

I concentrated to open my fist. Spell sank and mouthed the word 'sue.'

"You assaulted his wife, William.” Which wasn't quite true, but Lou was speaking Lawyer. The truth had nothing to do with it.

Our evening reminded me of bad marriages. Sadie wouldn't eat and spent over an hour in the bathtub, alone. I finished the shelves. Kept looking over my shoulder, but she didn't come down. Like a treaty - she wouldn’t mention out-of-place shoes, I wouldn’t mention out-of-character shoves. A man asks himself every day, how much can I bury? Answer is, a lot. Since I met Sadie, I make sure to ask myself, what am I burying with it? I went upstairs to make her talk and found her curled up in a ball on our bed, holding bundles of her hair, not making a sound. I forgot talking, focused on unbending elbows and knees, getting them around me. And the sex just happened, like it does when 
you're alive and in love, like Cara Plimpton would never know, because she'd died a mousy, awkward virgin, the kind Sadie had been in every adolescent photo I'd seen of her. To die sixteen, full of promise, no one to hold on to, nothing but size 9 high heel prints and a red smear to mark where she fell. I thought, For you, Cara, and licked the sweat off Sadie's temple as she came.

I woke at 5 a.m. by habit. The alarm was still un-plugged. I'd dreamed machine guns - hadn't had that one in a while. Sadie wasn't beside me. Blue light painted a trail to the living room.

The muted TV showed an airplane in a field. Sadie sat at the bay window with her forehead against the frame. "Crash in Oklahoma," she said. "The vans left to cover it. Pilot landed in a wheat field. A wing sheared off, and ten died, but he saved eighty people.” Tears spilled. "Lucky bastard.”

I clicked the remote to make darkness. The Major gave us some beautiful property. Sitting with her, I could smell shedding hickory and dying leaves even through the panes. I wanted to say anything else. "You have to tell me." She gagged, wept quietly. I lifted and turned her. Her chin had a shadowed bruise in the shape of my thumb print. "Sade, you have to tell me what you're leaving out. It's killing you."

She groaned like a haunted house's floorboards. I couldn't bury us, I wouldn't. "Did you see her get shot, baby? Is that it? Point-blank with a shotgun is terrifying. I've been there, too."

“It was just me and her." Sadie's eyes raised. Glassy. Cautious. "In the hall." Her. "You and Cara?" 
"She had a pass. She forgot a book."

I could see them, could hear Cara explaining. 'Hey, Mrs. Tomlinson. Yeah, got it right here.'

"She was asking what I thought about Debate Team. If I thought it was worth the commitment." Sadie kneaded at the carpet. "I saw him at the door. I said his name. He pointed the gun at me, at my stomach." She swallowed.

I was breathing too fast, so I slowed it. I could do that. I'd been trained to do that. "Tell me."

Wing E at one-thirty glowed white with afternoon. 'Debate's useful if you're looking at law school, I guess." Cara made a note - law school - on a college-lined sheet of notebook paper. Sadie hid a smile and saw the entrance doors wink at a new arrival. She squinted. "Harrison?"

Time went underwater, as a shotgun muzzle rose like Harrison's third depthless eye. Sun sparked off the pump gauge, and his Army surplus boots sounded farty on the tile. Absurdly, Sadie thought of opportunity cost, the definition - the value of that which must be given up to acquire or achieve something. Numbers scraped edges in her head: 1,400 students, 150 faculty and staff, 2 here and now.

Then the blast, and Cara burst like she'd been unbuttoned. She looked surprised, the way a baby does at an exploding balloon, as Sadie kicked off her shoes and ran to warn the others. 
"I pushed her. I didn't think about it. I pushed her in front of me, and he shot, and I ran.”

Sadie watched me. She saw my awe and wanted to know what it meant. I put my fingers to her temples, flattened palms to her cheeks, cursed this rotten world, and said, “Good.” I shook her. "Good.” Making myself a cradle, thinking of the Major in his double-time retreat, of me and machine gun fire and my friend standing in the way, of how war is hell and life is war and sanity is the stuff we do every day to deny those facts. How the math doesn't work, because what would I do for this single human being, how far would I go?

I pictured the field where the plane had crashed, pictured it shorn and blank and covered in a crowd of people. Harrison Bane had his shotgun, and he fired into masses thirty wide and fifty deep, Sadie at the very back. And for every person who fell who I didn't love, I said, “Good,” while Sadie cried herself to a hero’s troubled sleep. 


\section{HER METHOD}

I'm the Number 9. I pick them up and drop them off all over rural West Virginia. She's of average height, average build, and wears glasses. She carries a camera bag.

Steel hearts can't love or hate, they can only run. She steps up my steps, and I run her where I know she's going - to the covered bridge being torn down in three days. This is where they all go, the ones with the camera bags. The derelicts back at the lot think it's a shame how things are changing. They say a car crashed through the bridge's side before a new road got built - the road I run. I don't think it's a shame.

She sits and looks at passing country, at leaves beginning to curl like frayed timing belts, at birds the color of break lights, turn signals, traffic signs. She doesn't smile. It's as if she's searching for something between the leaves and can't find it.

She swings her bag and pulls my vein to stop me. New people pay their fare, she leaves out my middle. I won't miss her. Steel hearts can't miss, either.

I have stood in this spot for two hundred years and I will be gone in three days, though I connect land to land over water. They claim they no longer need me, and then they write on me with smelly paints from cans, saying Someone was here or For a good time call someone. I do not understand why my defacement is necessary to say one's past whereabouts, the location of good times. Lately, there is much that I do not understand.

A hornet's nest hums between two boards in my broadside's wide gash. A car crashed through the worn wood at my center, a red car. The police came to take a look, 
and they took this destruction - which was no fault of my own - as a sign I was weak. They decided to tear me down.

Tear me down? I connect land to land over water. What have they ever done? What has this woman done, this chippy in blue jeans with a bulky bag? She connects nothing to nothing. She is a disconnection. I know by how her eyes become far away at the sight of my graffiti and the jagged edges of my missing parts. She wants to take it and make it beauty, so her elbows angle, and her fingers make a ' $\mathrm{C}$ ', and her camera goes $w a$ chick and I am forever in her lens. I hope she steps in the hornet's nest.

I connect land to land, her to land, her to the boys who were walking downriver and saw her in the bend of late afternoon light. The boys are careful to arrive soundlessly. They are men who are eternally boys in some fundamental malformed piece. I can tell by their feet, the stealthy tread of them. They are soundless and not designed for soundlessness, whereas the woman has honest footfalls. She walks toward the hornet's nest and takes a photo.

One of the boys is tall and fat; one is short and fat. Tall puts his hands above his belly as if holding up heavy breasts, while Short gives himself a squeeze of pleasure. I have stood for two hundred years, so I have seen many things. I will be gone in three days, and there are things I do not wish to see again. Short treads my creaky plank. The woman turns. Her eyes come back from far away when she sees where the boys have their hands on themselves.

"No," she says.

“No, what?” says Tall.

She says nothing. 
"What'd you say no fer?"

She says nothing.

"You ain't heard the question yet."

There is no question. They are too close. They have made a triangle out of themselves, relative to the woman, so that she cannot run. As if on a signal, they creep closer.

She says, "Wait."

“Wait?” Tall says. He laughs, but he's waiting. So is Short.

She opens her bag and says as she slides the camera inside, "This thing cost me five hundred bucks. It's supposed to be waterproof. The bag, not the camera."

I can feel how her legs are shaking. Her very toes are shaking. But her voice does not shake.

Tall says, “Oh yeah?” He laughs again.

Short says, "That's some nice 'quipment," and lowers his zipper. He takes himself out with a shiver.

She nestles things just so inside the bag and zips it closed.

"You ready now?" Tall says.

She can hardly stand, but she says, "Are you?"

They start for her. She jumps on the wasp's nest with every pound of her weight and falls backward through the hole in my broadside. The short man gets stung several times in a sensitive place. I laugh beneath the boy-men's boots in perfect time with their running.

I connect land to land over water. Poor, poor woman. 
I am a we are a I am I catch her we ...

make ...

room underneath where there's room where there's beer bottles fish bones a red '97 Tercel she's bucking fight-kicking I win or I would except I'm . . . the ... same long enough for some surface and spit she screams ha ha come here come see ha come and see the bottom of me of the us that they call Shenandoah they sing songs they call Shenandoah but I . . .

am ...

more no-no-no can I keep you can we can we can you she's not listening she has something she has kicks and she spits and her method her method exploits when I'm ... the ...

same long enough for her surface screams no you don't you don't command me our nature you're not master of me and my fine grab it climb I bore of you I am more than you I. . .

am ...

This one reminds me of the freckly-faced knickbocker fellas, the way she catches onto my leafless remainders: they point like the finger of the grand old dame who used to 
scold the fellas down for summer suppers, and I would shade the dame as she scolded, and I would hold the fellas when they climbed.

I didn't take one side or the other. I rose so high above their squabbles.

They still talk about the storm that felled me. They talk about the storm, I mean they don't talk about me. They hung tires on ropes from the same place she's sitting, where she's saying, "Long as you're here," and laughing. She's crying after the laugh. She opens up a zippered bag, and as she does she says, "You're fine, you're okay, you got away this time, you made them scream this time," and laughs. The grand old dame's daughter laughed and cried against my side like this, and afterward her husband didn't come home again in his sharp old uniform.

This one clicks and briefly brightens, pointing herself far down shore. Her laughter and crying subside in turns - less of one, then less of the other, then still less of each - like lightning and thunder in retreating spring storms. Her head rests at one of my softest remaining angles, and I do my best to pat her gently, to hold her up. "Made them scream," she says again, her throat raspy and hard.

She sits for some time. The dame would sit like this, after her daughter hung a different rope from me, and a fragile neck along with it. The dame would let the knickerbocker fellas catch fireflies through summer evenings. Only the first night did she forget to put holes in the firefly jars. She had to explain to the knickerbocker fellas that the fireflies were dead, and one of them said, "Like Mother?" The dame slapped him, then covered her mouth, tearful. I patted the fella's hot, curly little head.

This one is thinking of chancing the current. She is tying her shoes around her neck and stuffing her socks in the bag. She says, "Can't stay here all night. They might be 
looking for you. They're pissed because you made them scream." She is doomed if she dives, because I towered over ones like her and here I am bleached, leafless. Now I steal the river's new toys, and the sunset paints its vicious ripples rose. There is a crack in me slowly filling with water's patient revenge. Apparently it isn't enough to begin as a seed, to punch through suffocation of soil towards light, to make sugar out of light, to grow. It earns nothing. How I wish I still had leaves to scold with, to stop her from leaving me, from diving as she does, and swimming like a swirl of brave madness. How I wish I had leaves to applaud with.

Prey sings. The soil cold, air a mist around my muzzle. Song-meat, stay. She hears me, fears me, sweet spice infusing aroma for the big and the bad. I wait so pepper flows into my meal on red rivers. Her eyes are moons with an eclipse in the middle, peering through the dark at my gray ruff, peering at what she has no defense whatsoever from, peering at my ears perched up high so I'll hear her wherever she goes. I'll hear her if she goes up a tree and I'll wait. I can't wait any longer. I pad toward her, slippery bounce, chup chup haunches in forest silence, which is never silent, and I am almost a leap away. But she opens a bag - miraculous things, they have so many miraculous things - and aims an instrument. Twitching finger pop-cha with light as white as my belly. White as her pink-white face, so afraid. I cower and whine. I'm angry, hungry still smelling her fear, like chicory root, tiding down from a tender heart. I advance again, the taste is worth - blindness! I growl and hit my head on - on a log, a dumb log. She walks backward, measuring steps and crying, singing, "Life is but a dream! Life is but a 
dream!" as though there's any help for her. If it weren't for her magical lightning machine I would be tearing through the pink-pale line of her throat. Fool! Fool for not being a fool, why don't you run like the rest of them? I trot to demonstrate and a moon explodes in my eyes. I whimper.

I sit on my haunches and watch her walk, hoping she'll trip or hurry, but no. I look at my own inferior moon, and I howl at it, telling my brothers: there is a goddess in the woods tonight, taunting us to kill her, and wounding us when we try. My brothers howl back that they do not believe me.

I content myself that soon I'll see a rabbit or a slow baby deer. And I'll prey.

I might as well hold the world together. Where the hell else would they put their dang clothes? Winters, the Missus curses me, just curses me, talks about getting a dryer and whatnot. But when I frost and split, I'm a cinch to repair. The pins cost two dollars for fifty at the store. The Missus talks about that. She talks to nobody but me, cuz her mister likes to stay in town on weeknights, getting his work done. I think part of the work he's doing is leaving his lady to blather in the backyard while she hangs the wash, that's what I think.

This ain't gonna put her in any feel-good mood - a gal doddering out of the woods like a drunk. But her shakes say she ain’t drunk, she's just freezing. Her clothes are dark and dirty and - those ain't yours! Who in the blazes don't just go knock on the damned door, that's what I'm not able to understand. "W-why w-w-wake the n-n-nneighborhood?" she says to herself, some stubborn Yankee girl stealing jeans and that 
sleeveless blouse. I'm bound to catch it for losing that sleeveless blouse, she don't even know. "R-road's r-r-r-right there," she says, “p-p-p-piece of c-c-c-c-" Piece of caca's what I'm thinking, cuz clothes don't just sprout outta nowhere. Then she fishes in a bag a bag that could sure use a few days in the gentle cycle - and clips a soggy twenty-dollar bill to me. That helps things, but it don't put 'em right. There's rules in the world for a reason. If people just take what's not theirs, then how can anything ever hang in the sunshine, that's what I want to know.

She points a contraption and makes the night day for less than a second. Good riddance.

Here is a girl printing bottoms of shoes on my winding body of dust. I wasn't always dust. I was this girl's grandmother. I'll be this girl's granddaughter. Why does she look so tired, when the sun's rising and making me shine tawny?

She talks to me. "You're fine now. You'll be fine." I will. I know. I will be - what will I be? I will be a repository for tire treads and footprints. I dream of the day the prints don't fade with other iterations and leave their patterns to be patterned upon. I dream of standing still, though I always stand still, and I dream of going everywhere, though I go everywhere already. I dream all day, everyday; all I do is dream.

I am a woman with a camera who can only find the beauty once I understand the thing. So I stand inside the thing, no matter how mechanical, no matter how damaged, no matter how dynamic, how tragic, dangerous, or obvious. I become the thing and it gives 
me itself in trade. Don't ask me why it works. Don't demand secrets I can't give you. Just look at this road I've managed to arrive at, and hear it pondering how:

She has dreams - I know she must. I want to hear them from her and hold them. I want to take her toward them. I am taking her toward them - I must be. But then why is she weeping at some sight ahead? Why does she say, "Knock off the crying," to herself and sniff a nose full of my body of dust?

She wipes her cheeks on a shirt too large and takes out a camera. I pose my only pose.

Why does she leave me for a bus stop?

Steel hearts can't be glad. Her shoes flap like flat tires as she climbs and pays her fare. She sits on the last bench, where she can see both doors, and smiles in a way that's not quite happy but isn't the opposite.

We both exhale when I stop at a bed and breakfast. She walks to the man who makes me run - a bearded grizzle with bad teeth. "Can I take your picture?" she asks.

The man tips his head. He wears a red cap that might have rooted for a team once but now just covers his comb-over. The flash goes bright.

She says, "Thanks very much."

“How you liking West Virginia?” he says.

She stops on my steps and turns. "I'm liking it fine." 
He says, "How's it liking you?"

She leans into the contours of me like she fits there. She almost does fit there, but only almost. She opens her mouth to answer, and it hangs wide just like my door. It hangs so long that the driver's bad, smiling teeth hide again, and his eyebrows make an angle like my wipers do in the rain.

The tourists who wait behind the woman all have cameras. They're going to the covered bridge that will be torn down in two days.

She closes her mouth, turns, finishes her exit and pats my 9 like I've done her a service. She doesn't ask permission, but I don't begrudge.

I can't. I'm only a number. 


\section{GOING. GOING.}

Tobias paces the ten-by-ten jail cell. The door is thick metal with a square of glass smaller than his head, and on the opposite wall, a window's bars stripe a starry night. He was arrested at a bar, he's pretty sure, and he suspects he shouted at somebody. His throat hurts. His head's a fug of hangover, but Tobias is used to that. What's got him pacing, his palms kneading, is the fact that his hands are sticky and chafed with streaks of dark brown that could be blood. He can't find any cuts on his hands. Tobias is trying to remember what happened, but it's like his memory is over-achieving. It's like his memory wants to make up for forgetting how his hands got bloody. So it casts back, back much too far.

Dad chewed tobacco, called it "tabackey." He spit the juice in soda cans.

When Tobias was eleven years old, Dad sold the farm. They moved to the city. Dad went to work as an agricultural advisor for a tobacco company. His poker buddy got him the job.

"Get this. Get this, I go in, right? I sit at my desk, right? Go to the water cooler, hit the vending machine. By Jesus, Dee, that's the whole job! I shit you not one speck of shit, Deirdre, that's the whole job and I've been there a solid week and I'm not leaving til they kick my retired hiney out."

Mom had gray hair and gray skin. She nodded a lot. 
The cot in the jail cell has a filthy mattress. The toilet's filthy, too. Tobias takes a piss, and his stream knocks a wedge of old shit into the toilet. While he pisses, he looks at the filth on the mattress and identifies blood, vomit, shit and piss. The cot is two feet from the toilet, to the left, and Tobias has turned left to look at the cot. His stream of piss has turned with him. He's pissing on the cot. He says, "Shit!" and turns back to the toilet, but too fast. He almost falls, then catches himself on the toilet. He's still pissing. Piss is on his pant leg, and his hand is filthy with old shit.

Dad said, "Get me the paper, boy. Fetch, go on. By Jesus, I miss the farm dogs, boy, don't you?"

Tobias hated the city. He hated their apartment, small as a doghouse, which he crossed in obedience to his father's orders. He hated their door, browned by generations of tobacco smoke, and he hated their hallway, loud in sound and loud in smells. He hated the stairs just because.

The radio said if you dug a hole deep enough, you could pop out in China. Tobias thought if he went down enough stairs, he could pop out on the farm. If he went down a million-billion stairs, maybe he could pop out in another time, another era entirely. He'd be a pioneer's son. He'd till and weed and he wouldn't mind. Tobias could handle the work. He was very big for his age. 
He passed the building's entryway and kept going down. It got darker down more stairs, like a country night, like a time and a place without electricity. Maybe Tobias would walk into a country kitchen, to a mom who handed him pancakes and told him Dad was in the field already, you'd better get milking. Maybe it was on the other side of this door here, at the dark bottom of the stairs. Maybe all he had to do was break this rusty padlock.

Tobias felt his mouth pinch like he tasted bad food. There was no homestead on the other side of this door. His eyes puddled and dripped, and that was okay, because his father wasn't down here to call him names for crying. There were petrified droppings in the corners, and oblong holes in the walls that shone quarters of light on Tobias's shoes: mice like in the corncribs in the barn at the farm.

As in the barn at the farm, Tobias heard mewing. It came from behind the door.

Tobias kicks the jail cell's door. It's steel, exactly as hard as it looks, and it breaks his toe. Tobias screams.

The guy at the bar might have screamed.

Tobias hates the window's bars, but he grabs them, because he'll fall over if he doesn't. He isn't big for his age anymore. He's begun to shrink. His dad didn't have time to shrink, dying before Tobias turned sixteen. Tobias was a starting defensive end as a high school sophomore. The night Dad was dying, he told Tobias - he wrote a note; he couldn't talk; mouth cancer took his tongue - 'Don't cry, faggot. Go play the game.' 
Tobias knocked everything in his path to the turf, screaming as he did it, smiling as he screamed.

He's screaming, "Brutalization of a prisoner!” but he's smiling, because he likes it in here. There's nothing to hurt in here except himself. Tobias punches the bars. One hit hurts horribly, so he stops.

He sort of liked the fifth grade, though the school building was a bug with a million eyes, and Tobias hated walking in it, being eaten by the bug. The playground was dirt, and the dirt got up your nose and on your clothes and in your hair, and Tobias hated that. The other kids all thought they understood everything about everything; for all Tobias understood, they did. And he hated them.

But Tobias sort of liked Vickie. Vickie had a cloud of soft brown hair that he sat directly behind for seven hours every day. He imagined shapes in her hair, like he used to imagine shapes in the clouds while lying in the fields on the farm after his chores were done. If Vickie had to pass a paper back to him, Tobias would feel a quick rush of heat as she turned. She had blue eyes like ocean water. She smiled at him once, when he got a bad grade on a Mad Minute, where they had to do quick division.

As she smiled, Tobias felt the heat fill his face. He wanted to tell her about the kittens in the basement. Behind that dark door, there must have been a furnace room or something, but the furnace wasn't there anymore - nothing was, except concrete, and a couple of oil stains, and the kittens. Six of them. They had little tiny bodies and great big heads. One had blue eyes like Vickie's, and light gray fur. He wanted to tell her, but the 
heat swelled his throat shut. She faced forward again. Her hair was a turtle that day, roped into a braid and looped low.

He's moving like a turtle, in the jail cell - slowly for his broken toe. Slowly for the beer in his blood. It never had to be good beer. Better, in fact, if it was cheap. Cheap was important when the football career ended at age twenty, flattened by a neck injury. Cheap was the back-up career, selling life insurance. Cheap was losing the job for being drunk on the job. Cheap was losing the wife for losing the job.

Vickie left him for a dentist, but it was over way before that. It was over when she cut off her cloud of brown hair, after she had Cecilia.

Tobias's legs buckle. He sits on the cot.

The delivery room nurse tried to hand him Cecilia, told him he could hold his new daughter. He was too big, exactly wrong to hold this exactly right thing. The nurse called another nurse to have him sit in a rocker and make a sling of his arms so the first nurse could put the baby on the sling his arms made. He watched his baby's hand rise up toward her face, like she was saying What's this? Oh, it's my hand. Who are you, you giant man? Why are you crying?

Tobias is crying, on the cot. He wants to be small. He wants to be new. He lays back so his head squashes into the place he pissed on the mattress, and he wishes to whatever god's got this frequency that he could go back to the second - 
Bobby Spence said, "Hey, you're the new kid."

Most of Tobias's classmates matched the dull used-dishwater wash that covered the city. But not Bobby Spence. Bobby Spence looked like he was made of gold. The boys followed him; the girls giggled about him. It had less to do with handsomeness with the light hair and dark skin a shock of contrast, the body big for its age but not like Tobias's, big for its age but lithe and fit - than with a sturdiness. A knowing.

Tobias had spent so many noon recesses alone that a person addressing him couldn't possibly be real. He'd kick pebbles in the dirt and watch Vickie on the swings. Her hair was a possum today - bunched on the back of her head and pinned there for a daylong nap.

Tobias said, "Yeah? I'm new."

Bobby Spence looked Tobias up and down. "You can be defensive end." Bobby was standing with nine other boys in a square bordered by tires. They used it as a football field. The other boys were behind Bobby, in a line.

"Okay," Tobias said. "Okay, Bobby, but hey. What's the defensive end do?”

The boys elbowed each other, whispering. Tobias tried to glare at them, but they seemed to blend into a mass. He couldn't find one face to stare down. He couldn't hear any one voice, specifically.

Bobby turned and looked at the line of boys. They stopped whispering. He turned back and asked Tobias, "What'd you play at home then, Ox?"

Tobias shrugged. "Baseball?"

He expected Bobby Spence to laugh. But instead Bobby said: 
"Get a bat!" Tobias shouts it, on the cot, in the jail cell. He jars awake from a vivid, ugly dream. He's thirsty. He goes to the sink and runs water on his hands. Dried blood flakes off his palms like freckles successfully removed. Tobias made a point to tell Cecilia every chance he got that he loved her freckles, and little middle Cee grew up loving her freckles, too. She grew up loved. Tobias was a good father, he really was. It's what he's proudest of. It's the only thing he's proud of at all.

It's a bitch getting dried blood off. That bitch at the bar called him a loser. He called her a bitch. He remembers, she was a loudmouth bitch, and he told her to shut up, he couldn't hear the game. It's Vikes-Packers so shut up, bitch. She had that boyfriend who said Tobias should come outside, he'd show him a bitch. Tobias went. Tobias went a little crazy.

"Get a bat," Tobias yells at the sink. He wants to stay inside the nightmare that's at least over. "Get a ball, get some bases, shit-heels. Let's make Ox feel at home."

At home, after Vickie left, Cecilia brewed the coffee that got him awake. Cecilia brought him the want ads. Cecilia cooked and Cecilia cleaned. And Cecilia was seventeen, then, and Cecilia had a boyfriend. The boyfriend came to the door. He shook Tobias's hand and called Tobias 'sir'. Cecilia looked at the boyfriend like he was a sunrise. Guiding her toward a brighter day far away from these mornings where she brewed Tobias his coffee and fried him his eggs.

Cecilia was obviously having sex with the boyfriend. Tobias waited up for her. He watched TV and drank beer under the lamp. He pulled her curfew back and back; he said it was for daylight savings. Cecilia said, "Okay, Dad," with an eyebrow cocking like 
Vickie's had when she thought Tobias was being stupid, and Tobias would grab her sometimes - Cecilia - when she did that. He'd shake her sometimes. He'd tell her he was sorry later. Tobias was -

"Sorry, Bobby. I gotta go home, it's suppertime."

One of the boys laughed. “'Supper'? Who says 'supper'?” This boy had a birthmark on his left temple. He kept his cap crooked to hide it. Bobby Spence called him Jamhead.

They'd continued the game from recess, picking a field in an uptown neighborhood with an open view of sky. Bobby Spence tossed the baseball in the air and caught it. "I gotta go home, too," he said. "It's suppertime at my house, too, Ox. Don't listen to Jamhead over there. He wants his mother to suck his dick and she won't." Tobias's mind did an odd thing. It became a serpent's tongue and forked at the end. On one side resided his mother and Vickie and soft mews behind a dark door. And on the other side was the fact that it was funny: Jamhead wants his mother to suck his dick and she won't. They were the same tongue, forked at the end. They were the same thought, maybe.

Tobias laughed. Jamhead angled his baseball cap more severely and mashed it to cover his birthmark.

Bobby Spence walked away with Tobias, and the other boys on the field dispersed. "We'll get you into football, Daddy-o," said Bobby. "You were made for football, Ox, I'm serious. I play quarterback, and I'm pretty damn good. My dad says I 
need better protection. He says I need a meathead to take some hits or I'll just get sacked, know what I mean?"

Tobias had no idea what Bobby meant. "Yeah, I know what you mean."

"So what I'm thinking," Bobby said, "is we teach you football and then you start on my team this year. You're big enough for the really good teams, but you should be on mine. They let you pick."

"But I like baseball."

"Baseball shmaseball." Bobby gestured at an apartment tower with a fountain in front. "That's where Vickie Turnbull lives."

"Really?" Tobias said, cricking his neck to take in the tower's height. The fountain had a bronze butterfly in the center. A baby girl in a yellow dress pegged a penny off the fountain's concrete edge, while her father held her steady.

"Vickie Turnbull," Bobby said, reverently. "You seen Blowhard, Ox? The porno? My dad's got a copy, I'll loan it to you. I picture Vickie as the girl, every time. The guy in the porno jizzes right on her face. It's dynamite."

"Hey, Bobby,” Tobias said. "Wanna see a secret? My secret place, you wanna see?"

Bobby Spence smiled. It was a weird smile, one that said he already knew every secret Tobias had. But then Bobby said,

"Sure," Tobias says, in the jail cell. "Sure, Ox, let's go." 
He has to shit, but he doesn't want to move. He's lying on the cot. The side of his face itches; it's been pressed to the piss-soaked mattress for an hour. He's pretty sure the guy at the bar was still breathing when they put him in the ambulance. Tobias only hit him three or four times. He'd have been fine if he hadn't fallen backwards and whacked his head on the concrete.

There's really no reason to move from the mattress. Tobias shits.

Shit, he thought, that night when Cecilia was out past curfew. He thought, Shit, because he'd had too many. He knew he'd had too many, but then he had two more. Cecilia, Cecilia sweetie, Cecilia my baby, Cecilia you bitch it's past your curfew. Tobias turned off the TV. He turned off the lamp. He sat in the dark until headlights rinsed the living room. The boyfriend's car idled in front of the garage. They didn't know Tobias was watching. The boyfriend's dark shape leaned toward his baby to kiss her, probably paw her, probably reach between her legs and fondle her. Tobias turned on the lamp.

Cecilia got out of the car. Her tomboy high-tops squeaked on the driveway. Tobias got out of his chair and wobbled when he stood. The boyfriend's car, which had been backing up, stopped. The car drove back into the driveway. The boyfriend was watching. Tobias was glad.

"Hey, Dad. Sorry we're late, we got caught in the storm earlier. Did you see it, it was really - Dad?"

Tobias, in the jail cell, gets up off the cot. Shit squelches in his briefs as he wobbles to the bars. He killed that guy at the bar, he's pretty sure.

"Cee," Tobias had said. "What have you been doing with him, Cee?" Cecilia stared up at Tobias with her big blue eyes. "What?" 
A car door slammed. Tobias looked at the driveway. The boyfriend was coming up the walk, past the marigolds that had gone to weeds since Vickie left. Tobias reached to the front door and locked the bolt. "I said," Tobias said, "what have you been doing with him, Cecilia?"

In the jail cell, Tobias cocks his fist far, far back. He hears her trying to answer him - “Daddy, no, we haven't. Don't, Dad!” - while letting fly with all his strength. He hits the bars and breaks his hand, just like he hit her face and broke her nose. He felt her nose cave in, under his fist, like his fist is caving in now, and again, and again - or like the guy at the bar tonight he's pretty sure he killed. He could have killed Cecilia, except the boyfriend took a rock off the neighbor's rock wall and bashed in the living room window and then concussed Tobias.

And then Tobias opened his eyes from the floor of his living room, just as, in the jail cell, he's opening his eyes from the cot's bloody mattress. Seeing in horizontal: his daughter bleeding on the floor. His daughter reaching for him, worried for him, crying, “Daddy! Daddy! Oh, my God, Daddy, wake up!” The boyfriend picking her up, taking her away. The boyfriend took her away, and Tobias hasn't seen her since, not in seven years.

Seeing in horizontal: the bars on the window, above the toilet. His hand is very broken. It's barely a hand anymore, more a claw. But it's only bars that he's hurt. Tobias loves this cell. He loves the bars and the cot and the toilet. He loves them even more than he loved the - 
“- furnace room, I think,” Tobias told Bobby, leading him down the dark stairs. “There's a couple windows really high up, so that's how the cats must've got down."

“Got down and got busy,” Bobby said.

"Yeah. I had to feed them from an eyedropper for a while they were so little. They can eat tuna now, though. I think something happened to their mom.” Tobias reached the bottom of the stairs. He took a flashlight he'd stashed in a corner.

Bobby wrinkled his nose at the mouse turds. "Mama cat probably found another john. She's whoring herself out somewhere.”

"Yeah," Tobias said. He opened the door.

The kittens swarmed him. They were still tiny, still the smallest things Tobias could imagine as alive. They nudged his big sneakers with their pink noses and rubbed their ruffs against his rough jeans. The blanket he'd left for them was wrinkled, so he smoothed it flat. He took one of ten cans of tuna off the windowsill along with his mother's extra can opener. He heard their chorus of excitement, and he bent and flaked the tuna onto a chipped saucer. The kittens crowded for the food. Tobias stroked his favorite's bushy gray back. Her blue eyes stayed glued to the fish.

Bobby Spence leaned in the doorway, his arms crossed. Tobias was afraid Bobby'd make fun of him, but Tobias wanted Bobby to know. He wanted Bobby to have all his secrets.

Bobby walked in the room and hunkered down. He picked up a pure white runt and held her carefully. She chewed on his pinkie finger. Bobby said, "Have you named them yet, 
cuz you gotta name 'em, Ox," Tobias says, and vomits on the cot. It's mostly bile. It gets on his hand, and it stings. "Gotta name 'em, Daddy-o, or else they're not really yours." Tobias laughs. He killed that guy at the bar. They're going to let him stay in this cell, or somewhere like it, for the rest of his life. They'll bring him food to eat, and they'll have a yard he won't have to mow. And when Cecilia visits, there'll be glass between them, unbreakable glass. She'll visit, because of the glass. Maybe she'll bring her boyfriend, now her husband, and the son they had last year.

He's safe now. They're all safe now. Tobias is crying, on the cot, in the cell, but he isn't sad. He's happy, he's so happy, he can barely remember

walking with Bobby Spence about a week after they named the kittens in the basement. Tobias carried the equipment. They were meeting the guys for a game.

"Football's where it's really at, Ox," said Bobby.

Tobias said, "Yeah. I guess it is."

“You're my number one guy, Daddy-o. We're gonna make so many touchdowns, we'll be in the record books. Yeah, Ox?"

"Yeah. Yeah, Bobby."

They went toward the city's giant green middle, where a scrubby baseball diamond lay forgotten, its fence rusty, its lines and bases gone. The guys were there already - Tobias could see them - setting down makeshift bases and toeing makeshift lines. 
"You'll take the hits for me," said Bobby. "You'll keep me safe, Ox, that's your job."

"Yeah, it is," Tobias said. "It sure is."

Tobias felt the weight of the box in his hands, but he couldn't hear the sounds inside - cabs and cars and hot dog vendors and barkers at folding tables covered in hardback books and people amidst piles of fake designer handbags and monuments to important men who'd murdered thousands and monuments to important murders of thousands more by murderous men - it was too loud, the city, to hear the quiet sounds.

But he could hear Bobby Spence saying, "Line up, shit-heels."

They'd all worn grubby Little League uniforms that were a size or two too small, just as Tobias had done. Bobby had told him to. Bobby'd said, "You got a loser baseball outfit, Ox? Put that on for the game today.” Bobby wore his usual jeans and t-shirt, but old, faded - stuff he could throw away.

"Hey, battah battah,” said Jamhead. Somebody shushed him.

Tobias left the guys at home plate. He went to the pitcher's mound and set down the equipment. He came back.

They stood there a minute, looking at each other but seeing something else. Seeing some wrong committed against them, or some wrong they were going to commit. Confused, desperately, about what the difference was. Angry, viciously angry, about their confusion. It was a Saturday, it was September, it was early, and the cold of fall condensed the breath around them like a foggy embodiment of what they were feeling. 
Bobby walked to the mound, and the others went to the bases and the outfield, Jamhead pausing to hand Tobias a shiny aluminum bat. Jamhead whispered, "Swing away, Ox."

Bobby opened the cardboard box's flaps and rooted around in its depths. He took his time, selecting the gray-furred female with blue eyes. The kitten curled so naturally into a ball. It was used to good treatment. It waggled a paw at Bobby's face, as if waving. Bobby nuzzled it. Then Bobby wound up.

Tobias smelled the bat handle's rubber releasing a bright tang under his fists. He shoved his back toes deep into the dirt. As the pitch came at him, he could see a blue as clear as a country sky in spring. And when he swung with all the power in his over-sized man-child body, his every cell seemed to burst with the mad-dancing terror of audacious, perfect joy. 
-ETTE

The clown is driving home. He sings 'Summertime' in his ugly, craggy basso since the radio doesn't work. He smells his car overheating, he smells barbecue, and it's tough to tell the two apart. It's a mild August for Knoxville, but more than hot enough. The clown can feel his left shoulder tightening up again.

His doctor said, "I swear, you've got the best and worst heart I've ever seen."

The clown said, "Wacka wacka, Nelson."

His street is the last and shabbiest of a shabby quintet of streets, elbowed out of the way by a mall that catches the traffic. At the head of his street, where a magnolia tree considers one more bloom before fall, Ana and Dori are sitting behind a card table. A sign with crooked hand-lettering promises 'Cold Drinx, 50ф'. A pair of pitchers dimpled with water hide all but the girls' foreheads and brown hair from view.

The Drinx stand's got customers. A kid the clown doesn't know is rubbing two coins together with one hand, swatting mosquitoes with the other. Kevin is pointing at the " $50 \notin "$ sign, then pointing at the cups, then pushing glasses up his nose as he does when employing fastidious eight-year-old logic.

The clown laughs. The clown's laughing because Kev's haggling a better price for Kool-Aid.

He pulls over and leans across the passenger seat. "Afternoon, ladies. This fella giving you a hard time?"

Ana and Dori smile around the pitchers. They're twins. They like to wear their hair in a big bun on either ear, because they think Princess Leia is the prettiest lady alive. 
"No thanks, Obi Wan," says Ana, smiling sweet around a pitcher of green.

"Yeah, no thanks, Yoda," says Dori, smiling evil around a pitcher of purple.

The clown puts a hand over his heart as if he's been hit by an arrow.

"He ain't Yoda," says the kid the clown doesn't know. "He's a clown."

Kevin turns to the kid. "He looks exactly like Obi Wan when he takes off the makeup. Dori just calls him Yoda cuz he's old." Kevin turns to the clown. "Obi Wan, fifty cents is too much to pay for eight ounces. Isn't it?”

The clown knows what a parent would say: Well, Kevin, how much is that per ounce? Or: Kevin, you can run home and make your own Kool-Aid if you're going to complain. Or, that worst of lazy non-answers: What do you think?

But the clown is not a parent. His wife's been dead for fifteen years, and they never had children. He hands a dollar out the window and says, "I'd like one grape and a cup of Luke Skywalker's choice, please.”

Kevin stands a little straighter. He's short for his age, but he has a dignity that makes him seem tall. Ana takes the money. She opens a shoebox on her lap. Her brow's a slipknot, her fingers bird beaks. She's trying to figure out change. Kev stops her hands. “A dollar's exactly right for two," he says. Kevin's in deep puppy love with Ana. He calls her 'Leia' when Dori's not listening. He's the oldest of the neighborhood kids, which is why he was the one that decided who was whom in the Star Wars of their neighborhood. Kev calls Dori 'Darth Vadar' behind her back.

The kid the clown doesn't know leaves the two-man line to squint into the clown's backseat. "This car fit a buncha clowns?" the kid says.

"What's your name, young sir?" 
"Tim. So does it?"

“Oh, if I need it to.” The clown accepts Kevin's offering of a Styrofoam cup. Vivid purple kisses the brim. "If I need to, I can fit a thousand clowns in this car."

"Can not!"

"Oh, yes I can, Tim. Oh, yes I can."

"He can do anything," Kev says. "He’s Obi Wan."

The clown is satisfied he's made an impression, and that leaving now will leave a mystery. This is the trick with children.

The girls skimped on sugar and overdid the ice, but the clown still loves the taste. It takes him back to where he grew up, five miles away. He could drive there, but he'd only see another mall. His current neighborhood has houses that were made of strong wood, but it's sad the way the window frames seem to bow.

"Now, none of that," says the clown, flicking his key to cut the motor. He looks at the bright summer sky and says, "Yes, dear. None of that, I know."

"None of that," she said. That was the last thing she ever said. He was crying on her hospital sheets; they reminded his nose of ashes. She said, "Now, none of that," and then she died.

"Well," says the clown. "Well, what do you do?"

His left shoulder aches very badly. He thinks about his pills up all those stairs. He thinks about how Nelson said a third heart attack would just about do it. "And," Nelson said, "here's a scrip for some pills. And keep them on you. And take one when you feel that arm tighten up like it did the last couple of times, you dummy." 
"Sure, Doc," the clown had said. "Yeah, Nelson, sure. Remember Ricky Pistone? Who's a dummy, my good buddy?"

"I was ten."

"So was I. I still said don’t egg his car. Didn't I?"

The clown throws his emptied cup behind him. There's a mess of mostly paper back there: receipts for gas and oil changes, circulars left on the windshield, take-out boxes hollowed of food. There are frayed wigs and split clown pants from three sizes ago, and extra greasepaint. He tries to think of the last time he cleaned out his car. He works backwards, back to buying it, right after his wife died. He had it painted pink with primary-colored balloons, because that's what a happy clown drives. He can't believe he hasn't cleaned this car in fifteen years, but he hasn't. He really hasn't. Not the whole time he's been a clown.

He asked her when she got sick, "What do I do now?"

She said, "Make 'em laugh like you make me laugh."

He asked when Nelson gave him the scrip, "Nelson, what if I feel an attack coming on and I can't get to the pills, what then?"

Nelson frowned and said, "What kind of question is that? I said keep them on you."

The clown's building is narrow, like an illustration from a fairy tale. Stairs curl around the outside of the building like vines. There are four floors, and the clown lives on the fourth floor. There's no air conditioning. There's no elevator.

He shouldn't have done the pratfall routine today, but he couldn't help himself. The girl's parents were so poor. The girl wore a paper crown. Nobody at the birthday 
party spoke English or any language the clown recognized. Old carpet, old sofa, old clown in an old living room with an audience of a dozen kids antsy for cake. The clown thought, The pratfall routine's perfect for this.

He thought of Nelson: One more heart attack should just about do it.

And the kids laughed. He tripped on nothing, and they laughed. He begged them for help and tripped while begging, and they laughed. They laughed those kid laughs that are screams at the beginning, stutters after that. Their tiny bodies did helpless somersaults on the old carpet, in front of the old sofa, the old living room filling with cooking smells foreign to the clown. The birthday girl's paper crown hung wilted off her head as he told her goodbye. He was tripping backwards down her driveway, waving both white gloves. She was leaning forward, holding her belly, eleven friends behind her, laughing.

The clown remembers he didn't ask the girl's parents for payment.

"I forgot," he says, in the car.

His wife says, "No, you didn't."

He grabs a handful of paper from the back seat. He takes a grocery bag from the passenger side. He puts the papers in the bag and keeps on doing this for a half-hour. He feels some of his makeup dripping off, the ache in his arm getting worse.

He looks at the sky, where the sun's walking toward the horizon, making the housing developments on the hill glow white, and he says, "Edna, I just forgot. I forgot the pills, that's all."

"You've gotta live, Wally," she said to him. "You've gotta do good in the world, then come see me when you're done. You were a trickster sometimes. Probably not bad 
enough to count, but Wally. Wally, do some good and hedge our bets, okay? Now, none of that."

The clown opens his car door and takes five bags of garbage to the big green dumpster. It's hot out here, humid. His arm is sending more heat through his body. He thinks of his heart like the handle of a light saber - what color was Obi Wan's - and his blood as a glowing beam so hot it cauterizes while it cuts.

"Hey."

The clown looks at his building's first floor door, which hangs open.

"Hey, you got a permit for that pile?" A stooped relic nods at the clown's car while turning up two hearing aids.

"It's a pile but it's mine, Treadway."

"It's a pile and an eyesore."

The clown locks the car. He starts climbing the stairs, counts them as he climbs.

“How’s Goldie Hawn?” the clown says. 1, 2, 3.

"She's blind. Bounces off the walls like a damn idiot. I should put her out of her misery."

5, 6. Treadway's been saying this since Goldie was a puppy. Back then the reason was noise and incontinence. 8, 9, 10 .

"Sorry to hear that."

A door slams under him.

12. He stops at the second floor landing, puts his elbows on his knees. He can't breathe. The air's water and it's drowning him. He's smiling.

A voice says, "Who - oh hi." 
The clown feels hands pulling him toward cool air.

The voice says, "Oh, no. Oh, no."

The clown can't stand up anymore and it's good timing, because he's somehow made it to a chair. A breeze rustles his red wig. He breaks wind and feels humiliated about it. He tries to say 'Excuse me,' but his breath isn't back yet.

"Here. Try drinking that. Drink slow, okay?"

The clown purses his lips, fills his mouth, and swallows. He recognizes the jolly false flavor of grape Kool-Aid, and he laughs. He has enough air, now, to laugh.

Edna told him, "You'll spend your last breath smirking at me, Wally. I can't decide if I love that or hate it some days."

"Edna?" says the clown.

"Olivia," she corrects, sitting on the dull-edged table beside the clown's chair. "We've met, Mr. Bowman, remember?"

"Yeah." He tries to see in the dim room. "Of course, sure. How are you?"

The drained cup leaves his hands, Olivia saying, 'I'll fill it again. Just chill, all right?"

She's young. He's not sure how young. She's very pale. Her hair is cut in short snarls and spikes. The first thing about her the clown ever noticed, as he handed her banana bread he baked in welcome two years ago, were her hands. On the left, below the knuckles, was tattooed the word 'LOVELY.' On the right, mirroring it, the word 'LONELY.' The script was messier on the left than on the right. The clown suspects she did them herself.

Olivia returns from the kitchen. "Should I call a doctor?" 
"Nah. Really, I'm fine." He toasts her with the Santa mug she gives him. "Hits the spot."

Olivia sits on the coffee table again. "I'm almost done," she says, eyes alight, yet colorless from lack of light.

"That's great," the clown says.

"Do you wanna see it?"

"I'd be honored."

Olivia bounces off the coffee table. He gave her the banana bread two years ago. She asked him in, haltingly. She sat him in the same chair and sat herself on the coffee table. She brought him this.

"See?" she says.

It's a stack of paper. It's an immensely large stack of paper. Words march marginless across the white like an army in an infinite desert. The clown pretends to read some, but he's already read as much as he cares to. There are no capital letters or punctuation. There are lots of people killing each other in gruesome ways. There's a girl trying to stop it, but she can't.

There's enough of that happening, thinks the clown. Why make more?

The clown says to Olivia, as he has at least twenty times, "It's brilliant." "You think?" Olivia says.

"Yes, ma'am, I do. And now I must be off."

“Okay. Thanks for the banana bread." Olivia tells him this as though he just gave it to her. When the clown touches the doorknob, Olivia turns from her kitchen's threshold. "Careful on those stairs, Mr. Bowman." 
"I'll do that, sweetheart," he says. "Keep crackin' on that. It'll change the world."

She has a nice smile - no chipped teeth, all straight - and her nose has the faith of shape that means it's never been broken. Whoever hurt her worked from the inside. That skinny body wouldn't make more than a thread of silhouette if she let the sunlight angle across her. Which she doesn't. She smiles at the clown, her legs a step ahead of the widening orange shock in her dingy living room. His gaze falls to her crafty feet.

Edna loved to dance. He didn't. He'd tell her that - 'C'mon, hon, no dancing for me.' - and it would kill her a little. There was a dance going on in her eyes already when she'd ask him and that dance would die when he said no. He said yes sometimes, but mostly he said no. He's aware it's a stupid thing to feel bad about, all these years later. The clown says, "Hey, Olivia?” He has nothing more to tell Olivia, but he thinks if he could get the sun on her skin, even for a second, then it would start a chain reaction reverse-wounding. It would undo whatever's been done to her. “Olivia, hey!” And then Edna's eyes full of dying dances would recede because the clown did this good thing. He'll have done one more good thing in the world, like Edna said to do. "Olivia?"

But Olivia doesn't answer. Water runs. The clown stands in the open door, his shadow saddling a dusty blue sofa. He pulls the door after him, watching the room's ghosts take their places.

The heat of the day is burning itself out on sunset, sick of its own excess. The heat in his chest has burned out, too. The clown dirties his white gloves by grabbing the raw wood rail that faces his street. He sees Ana and Dori's dad carrying a table toward their house on the corner, Ana and Dori each with a pitcher, following him like laden baby 
ducks. Kevin's carrying the money box in two hands. He dresses like a banker, does Kevin. The clown finds his leg springing up to take two stairs at once, then two more.

"Wally," Nelson said, "the bad news is, you've got a bad heart. The good news is, you've got a good heart."

"How many versions of that joke you got stored up, Nelson? Do I get to hear 'em all before I buy the farm?"

"Wacka wacka, Wally."

The clown knows a heart can explode. He's felt the minor ones - the grenades, say. He's curious about The Big One, and he hopes he'll have some time at the top of these stairs - a couple of seconds after his aorta plus four chambers are jelly in his chest to say something wise and good and wonderful to the D'Tomasos who live at the landing before his in four, make that two, make that no more steps. The clown doubles over, retches dryly like a dog. His heart beats pain through his blood, pure pain. He feels it in his eyes and his toenails, his testicles, knees, knuckles. His heart beats, but it doesn't explode.

But it will, he promises himself. And the D'Tomasos will open the door when I drop. And they'll be shouting Spanish at each other, but the kids know English. Ezzie, the eldest - Esmerelda, God what a beautiful name - she'll ask me something. She'll ask if I'm tired. She's six, she's got a huge crush on Kevin, but Kevin loves Ana - God, God, it never changes - and I'll tell her yes sweetheart I'm very tired.

There's a note on the D'Tomasos' door:

"Defeating the heat. Lake house 2 days. No mail, yes?" 
The clown laughs, and the laugh hurts. The laugh is brown glass in his lungs. He goes to the last eight stairs, taking them one at a time, telling them what he'd have told Ezzie.

"I'm tired. I'm so very tired."

He's gained the top landing. He dizzies, wobbles backwards. He hears the railing splinter. He sees himself falling four stories, splattering Treadway's doorstep.

But the kids, the kids might see.

The clown throws his weight forward, as the railing's last shreds give up their right angles and hang, broken. They don't fall, and neither does the clown. He's holding his doorknob.

"Sweetheart," he says," I forgot my keys."

"You don't fool me, trickster, they're in your pocket."

He checks. Edna's right. He puts his hands against his door's cheap squares of glass. The glass is paint-stained at the edges. He puts his forehead against his hands. "You weren't always right," he says. The clown begins to cry. "You said to me, 'Don't pretend I was an angel once I'm gone, Wally. I could be a real you-know-what and youknow-it.' You said that when they told us there was nothing else they could do. So why is it everything I do some days I think, 'This'd be perfect if my angel was here?' Huh, babe? Why?"

He feels foolish, not least because the black around his eyes and the red around his mouth are smearing onto his white gloves. The clown takes out his keys and unlocks his door. 
A fly floats in, flies to the window to the right of the door. The fly begins to crawl up the window's screen. The clown says, "Get on out, then," holding the door open. But the fly stays flat to the screen, occasionally panicking and falling. "C'mon, buddy," the clown says. "C'mon, here's freedom." He swats with a stained white paw, but the fly fights to remain at the window. "Fine," says the clown, "stay to supper."

There's the air mattress the clown sleeps on, the two of each dish he eats off of the second of each dish not necessary because the clown never has company, but he couldn't bring himself to buy one plate, one cup, one fork, knife and spoon. There's four hundred square feet to look at - a converted attic with a kitchen so small and inconsequential, it can barely be called a kitchenette. It's sweltering. There's the oak rocking chair he gave Edna when they married. For the babies she'd rock to sleep.

"None of that, Wally."

"I can’t, babe. I can’t anymore."

"Why today?"

"Why not?"

"Wally, you've gotta do good. Do good in the world so you can come up here when you're done. Do good things. You've gotta."

The clown stands at his door. He imagines sitting in the rocker to pull off his polka-dot balloon pants, standing and removing his fluorescent-striped shirt. He sees himself doing it, right there, a few feet away. He sees himself reaching to take off his oversize shoes. Except he changed shoes to drive home. And then he threw his oversize shoes in the dumpster, with the garbage in his car. He almost says out loud, 'Now why'd I go and do that?' but before he can speak, he hears a trombone. It's six-thirty. Kev 
practices trombone every evening from six-thirty to seven. Kevin's playing 'Summertime.'

The clown looks out his window. He sees his street and the streets before it feeding into a thoroughfare that goes in two directions - east toward the mall, west toward the river. The river's like the outline of a woman, lazing in front of low mountains. The mountains' outline resembles a woman, too. It's been fifteen years since he had a woman. His friends tried to set him up a couple of times, but it felt like he was cheating on her. It felt unfair to feel that way, but what can you do?

His shoulder is a banked fire, fluorescent orange under thin gray ash. The clown starts singing along to 'Summertime' and dancing a bad shuffle. He imagines the fly is his partner.

Then he practically runs across the apartment and pulls the stopper on his air mattress and takes a roll of trash bags from under the kitchenette's miniscule sink. He sinks into memory while the trombone moves on to 'Minuet in G.'

He didn't know how to approach her. She was beautiful, was honest-to-God stunning. She wore a simple black dress, but her body turned it into pure magic. He figured she must know it. He said to his buddies, "That girl's a knockout and knows it," and his buddies nodded, scanning for smaller fish. The American Legion sponsored the mixer. The meeting room had four or five tables, a patch of cleared floor, napkins matching plates, a punch bowl. It was supposed to be a dry event, but all the guys had flasks except him. Some of the women brought flasks, too, but not the beaut in the corner. He said to his buddies, "That girl's too good for drinking, fellas, check it out." As the night wore on, though, she was still standing there. He'd danced with ten girls - Wally 
had - and the stunner hadn't danced once; he knew, he'd been watching. So the next time the DJ played an up-tempo number, he took all his guts and walked over to her. She was eating a finger sandwich made of cream cheese and cucumber.

"Dance?" he said, too loudly.

She looked around for whomever he could be talking to. She said, "Me?" on a mouthful, her eyes big and unbelieving.

He couldn't talk. That was it; that was all his courage, practically hollering the invitation in her face. But he found he could nod, at least. He found, also, that in the couple of seconds while she put down her napkin and stuffed the rest of her finger sandwich in her mouth - her cheeks bulged like a bullfrog's - his mind kept rehearsing what he'd tell his buddies after she said the 'no' she was obviously getting ready to say. He'd tell his buddies, 'She ate most of a sandwich in one bite, fellas. Looked like a bullfrog when she did it. Class and a half, huh?'

"Well?" she said.

"What," he said, forgetting to adjust his tone of voice from the fantasized putdowns he'd tell his buddies.

"Well, are we dancing or not?" she said. "Make up your damn mind." He said, "Jeez, aren't you something."

She looked at him levelly, though the top of her head was the height of his shoulder. She looked at him like she was saying: Yeah, I'm something. I'd better be. He waited. She waited. It was a battle of wills, and whoever talked first was the loser. 
But a thought occurred to him, blowing like a summer wind through his mind. He thought: Maybe this battle doesn't have to have a loser. And finally he said to her, "You're something."

For a terrible moment, he thought she was walking away from him. Then she turned and held out her hand. They'd been staring at one another so long the song had changed to a slow one. He got to hold her close and smell her perfume. He thought, as the song ended and he couldn't let go:

"I'm in big trouble here." The clown is standing in front of seven trash bags, a line of them leaning on each other like childhood friends. The bags are piled in front of the window, whose screen the fly still interminably travels. The clown is talking to the fly. 'Down's not so bad, but up? Up about killed me an hour ago. I don't know if it's in me, buddy, I really don't."

He opens the door and tries again to scoop the fly to open air, but the bug's too damn dumb to understand there's more than one way out. "The hell with you, then," he says, and lobs a trash bag over the broken rail, checking first for any kids in the driveway.

He throws the bags containing his inflatable bed, his dishes, his pots and pans, his food, his magazines and books, his photographs, his shower curtain, his shower curtain's hooks, his two big towels, his four small towels, and the entire contents of his medicine cabinet - including the pills that would make his heart pump blood instead of cement.

“Oops,” he says when he’s done. "My pills're down there."

He starts down the stairs. He's carrying three items. He gets to the D'Tomasos' door, almost vomits. He bends - it's excruciating to bend - and places a copy of Robinson Crusoe on their Bienvenudos mat. His head swims. The muggy air's begun to 
turn a soft orange, like something you'd drink with breakfast. Only it's dinnertime. The families are eating dinner. He reaches Olivia's door. He bends, but can't go more than halfway. He doesn't want to shout - if he shouts this time, she'll call 911 for sure - he just needs his pills, he threw them out with the trash, what an idiot he is. He leaves the greasepaint kit on her threadbare Welcome mat. Maybe she could go out if she had a disguise, is his logic. He's most of the way to the bottom. He can feel the fission, the reactor inside. He's just gotta get to those pills, he threw them out, goddamn Wally you're dumb. He drops the box of dog treats on Treadway's total lack of a welcome mat and pitches the seven trash bags into the big green dumpster. He remembers only when poised to go upstairs again that he just threw his pills in the dumpster.

"Oh well," he says. "I'll get a refill tomorrow."

Nelson said, "No waiting on refills, fella. You get low, you get more the same day. Got me, Wally?"

He wheezes, "Nelson, remember Edna at that mixer? Remember?"

Nelson says, "Sure do. None of us had the stones. Or were stoned enough."

He's at Olivia's door. The paint kit he left is already melting. "She told me to do good, Nelson. I gotta do one more good thing. If I can do that, I get to go be with her, buddy."

"Refills, fella," Nelson says, "refills."

He's at the D'Tomaso's door. There's a crow pecking at the book he left. "I can't save 'em, Nelson. I can't save any of 'em, can I."

“Third attack," says Nelson. "Do it." 
He's at his own door. He left it open for the fly, but the fly still crawls across his window. He goes inside, shuts the door behind him. He couldn't think how to get the rocker down the stairs. He's thinking, I'd better get that rocker down the - when his heart tears, the force of fibrillation like nuclei uncontrollably dividing. The clown drops. He's propped with his back against his door. He thinks, I want to be in my chair. The last of his over-white complexion is washing away in this tiny oven nightmare of an apartment, on this rotten stinking cancer of a city, part of a despicable world that robs a decent heart - maybe not good, but at least decent - of the chance to earn a ticket somewhere better. One last goddamn good thing was all he needed to do. The clown is weeping and railing at God, but only inside, as outside he is busy seizing, filling his pants, feeling his heart attack him.

"None of that," Edna says. He hears her, to his left. "None of that now, Wally." He turns his head. The fly climbs the screen to the very top, then panics and descends. It hurts to reach, but the clown's thinking, One good thing just one good thing. The clown reaches, even though his heart is now in pieces. He shoves the screen with his filthy white glove. It's the second-to-last thing the clown ever does.

The fly floats through this new gap, to a sky golden with endings. It does a turn in the air, a perfect pirouette. The last thing the clown ever does, is smile. 


\section{DADDY RADIO}

Marcus lost the head coach job to an out-of-stater, an offensive coordinator at a low-ranking NCAA team from the south. When Tom Wafford gave Marcus the news, in the lush principal's office with its potted spider plants and well-appointed furniture, Marcus's main thought was: You are not my friend; I hoped you were, but you are not.

"I’ve spoken with him," Wafford said, meaning the out-of-stater. "He would love it if you'd stay on as assistant coach."

"I'm sure he would," Marcus said. "I know the boys. I know the competitors. I know the equipment -"

"Listen, Marc."

“- all of which would seem to make me the ideal candidate for this position. So I don't understand, Tom."

Why had he said that? Of course he understood. Now he'd painted himself as an idiot, a sore loser.

Tom folded his hands over a paunch that seemed to enlarge along with Vanderbilt High's dropout rate, as if the principal were eating the children who never came back to class. "This guy has ten years experience on a college team."

"Yes, and I have twenty years with this team." Marcus couldn't help going into detail - his frozen fingers signaling plays from snowy sidelines, his hands splinting boys' sprained ankles on rain-soaked benches, his ears numb from headphones as he sat above the field in the stuffy press box, his back locking up when he showed the twentieth batch 
of freshman how to rush a defender. You are not my friend, Marcus thought as he said all this. I hoped you were my friend, but you're not, you bastard.

When Marcus was done, Tom reclined in his ergonomic chair. "Am I hearing a resignation as assistant coach? Or is this just posturing."

Marcus got up. "Yeah, I resign.” He dug in his pocket, found a five-dollar bill, and threw it on the desk. "That's for your time. I know how valuable your time is."

A bell rang, signaling the end of his free period, and Marcus stormed the crushed hallways, where he was once a hulk among the squeaky-voiced, sweaty-pitted males. He'd begun to shrink with age, his shoulders stooping. A new coach doesn't want the old guard hanging around. Especially if the old guard wanted the job, tried for the job, and the boys know it, the boys are good boys, loyal. That would be a problem. Unless the man in charge knows how to hear a resignation where there's none.

Marcus didn't tell Nadine. He got home, threw his pocket change in a dish on his desk, stepped out of slacks and into jeans and went toward the garage. Nadine called from the stove that dinner would be ready in an hour - tuna casserole. Marcus made a noise of sarcastic approval. His wife caught the approval but not the sarcasm.

"Tell Daisy," Nadine said, "that if she wants to come home late without calling, maybe next time we'll eat it all."

Marcus pretended to laugh. He shut the door on her voice. He flipped on a cruddy clock radio tuned to NPR and looked for something to do. There was the minivan, royal blue and unnecessarily large now that Daisy was the only daughter left in the house. 
Marcus considered changing the oil, but he'd changed it two weeks ago, and three weeks before that. There was a gaping space where Daisy would park her Dodge Dynasty - an immense, grandmotherly car that she called Louise. There were sleds hung on pegs - a small red disk, a smaller orange toboggan. There were ladders for chores he'd already done and shelves glutted with worn sports equipment. Not real sports: girl sports. Marc went to his workbench, tipped a jar of medium-sized bolts onto the counter. Then a jar of large bolts. Mixed them. He picked the sizes apart with careful, tweezed fingers, agreeing and disagreeing with All Things Considered, wishing it were the weekend so that Lake Woebegone discussed something other than politics. But everything was politics. Every damn thing.

The garage door kicked to life, folded to let the April sunset in. A powder blue Dodge Dynasty revved a joke at him - Think I won't run you down, old man? Marcus smiled, put his hands up. The car crawled forward, the way he'd taught her, careful, a car is not a toy. The motor cut and tic-tic-tic'd while Daisy bopped out, her soft hair in a loose ponytail, smile dimpling her chin.

"Yo, Dad."

"Yo yo," Marcus said. "Sweet ride, Grams."

"You like her?" Daisy bent as if she'd suffered an injury. "My hip!"

They laughed. Marcus felt danger in his laugh, like it could become hysterical, could become crying. "How were the howling dogs?"

"Dad." She swatted him in passing. "Don't call them that."

Daisy did musical theater. She was the only one at Vanderbilt who could sing. He called her co-stars howling dogs, and she told him not to. She was in dress rehearsals 
now. He could see a stripe of makeup on the outer border of Daisy's face. He pointed at his own face to show her.

Daisy took a break from unlacing her boots. She got the boots at an Army surplus store; Nadine had thrown them in the trash four times, and Daisy had four times rescued them. She wiped the foundation onto her sleeve. "Yuck."

"Hazards of being a star."

She scrubbed until her shirt had a fleshy stain all along the forearm. "I'm a chorus member, Dad. Seriously.”

"That's because you're only a sophomore. It's a seniority thing." He tossed a rusted bolt at the trash, too hard. It ricocheted. "It's all politics, hon."

Daisy frowned. "Hear about the job yet?"

She looked so hopeful. She looked nothing like him. He loved that about her. He shook his head.

"God. Dad."

"Don't tell your mother."

"Why?"

"I'll tell her. I'll tell her later on tonight." He fled Daisy's incoming hug, sidestepped to the Dynasty. "How’s this running?"

He heard a brief silence, while she sifted through the mechanical snafus she'd sited lately. She never said it was running fine. Not if he was in the garage. "The brakes sound a little funny."

"Funny how?"

"Shrieky, kind of. Kind of howling dogg-ish." 
"I'll check 'em out." He heard more silence, her debate about whether to press. "Go on in." The door opened, closed. He got out the WD and a stool he'd made with his own hands when Daisy and her older sister were so young that it served as a tea party chair. He didn't need the extra light, but he plugged it in anyway, for extra illumination of these perfectly fine brakes. He took them apart and put them back together after jacking the car up, removing the tire. Maybe it was the other front wheel. Or one of the rears. He'd check them all.

The door opened. "Dad? Supper's on."

He told Nadine. That night, in bed. She said, "Oh, that's too bad," and turned away from him, yawning. "You said you didn’t want it that much anyway."

"Right."

"Well." Fifteen minutes later, she was asleep.

Marcus taught English. He knew it was overdone, tired, to be lying here and roiling in a midlife crisis. He knew it, but he couldn't not do it. He couldn't not revisit being twenty-one and meeting Nadine, Nadine seeming so full of life and spirit and excitement, dancing at every party, up for any party, flaxen-haired and perky-assed Nadine, who, he found out in marrying her, had been acting the part of a woman full of life and spirit and excitement, doing the dance of enthusiasm at parties, pretty 'til she took the contacts out, washed the hair products off, had babies and lost her perky ass.

They'd met in the early seventies, but Nadine's parents were strictly forties. They'd taught her: find a man and lock him down and he'll provide and you'll stay home 
and fold towels. Marcus fell for it because he'd wanted to fall for it. He hadn't wanted a woman, back then, who knew her mind. He'd known women like that in college, had slept with a fair few of them, and they were exhilarating, but he'd posited the exhilaration would turn to exhaustion over time. He tried to count friends of his who'd married women like those, but the truth was his friends remarried women like those, like his friends had lain awake having exactly these thoughts, had recognized an error, had corrected it.

He'd thought of the head-coaching job as an alternative fix, as leading the boys into an undefeated season, having remedied the flaws in old plays. His success would catch the notice of a college team on a losing streak. Abundant tears would be shed at his departure, but they would know it was for the greater good, that Marcus was meant for pro football, where he'd be promoted after an unprecedented showing at the college level, then on the sidelines of the Super Bowl before anyone knew it. He'd have reached his professional apex before he was kissing distance of retirement age.

A dim wedge of light showed around the bedroom door. Marcus got up, slipped out. He passed Nadine's bathroom with its two sinks, meant to be shared. He passed the laundry room and his bathroom, meant for guests. He stopped and looked at the lamp haze lighting the kitchen. The light came from the bigger TV room.

The big TV wasn't on. Daisy was reading. She didn't sleep much and hadn't as a baby, either, but she hadn't cried. Marcus and Nadine had lain awake and listened to her gabble. Sometimes it sounded like she was singing, and sometimes it sounded like she was talking. Marcus believed she was singing herself lullabies, telling herself stories, 
before she could talk. And nowadays, when he asked her if the insomnia bothered her, she just shrugged, snorted dismissively, said, "I get more done this way."

It worried him. The life of her mind was so exhilarating that she never completely left.

Marcus went back to the bedroom and locked the door behind him. He got in bed and woke Nadine by climbing on top of her, covering her mouth.

"Mph?" she said, startling. Then she saw who it is and nodded, shut her eyes.

At the sound of the bell, the students flew past his desk, depositing quizzes in a messy pile that Marcus straightened once they were gone. He had seventh period free, and no gutting job rejections to get through today, so he could sit back and wait for her. She arrived as the PA system made announcements about messages in the office.

"Yo," Daisy said.

"Yo yo. How's the day?"

"Eh. Yours?"

"Fine."

She had history seventh period, but she came to Marcus's room to chew the fat for a few minutes. Usually, they talked past the bell, and he wrote her a note to excuse the tardy that would be forthcoming if her father weren't a teacher in the school.

Daisy said offhandedly, "You tell Mom?"

"Yes. I did."

"What'd she say?" 
Marcus flicked a rubber band at the board, where he'd markered notes about Jude the Obscure. "She said it was too bad."

“That's all?" Annoyance.

"I didn’t really want it."

"Yes you did."

Marcus read the obvious insights he'd made about Hardy. Jude is the patron saint of lost causes, kids, did you know that? "You should get to class. Mister Schmidt's getting ticked about these notes, I think."

"Dad," Daisy said. She waited until he looked at her. She looked so little like him that sometimes it made him suspicious. "You really wanted it. Don't insult my intelligence."

“Oh,” Marcus said, "anything but that. I'd sooner die than do that, Daisy. How are things on the dating front?"

"What?"

"I'm concerned. I heard a rumor you're a lesbian. You can talk to me, you know." Her eyebrows daggered. "Yeah, except we've had that talk, and I told you, a couple of my friends are, but I'm not. Okay? I'm fucking not."

"Stop cursing."

“Stop displacing." She stood up. "I wish you'd gotten the job, Dad. I'm really sorry you didn’t. I really, really am.”

“This has nothing to do with the job. I'm worried. I'd like grandchildren someday."

She compacted into a crouch of horror. "I'm sixteen! Jesus!" 
"Do not take the name of the Lord in vain in my classroom."

"Oh my fucking God," she said, and breezed for the door as the bell rang.

"Hold on, I'll write you a -"

"I'll take the tardy." The door closed.

Marcus went and picked up the rubber band. He'd been completely justified. She should be dating more. She should be going out. She read too much, she was too thin. She should eat more, read less, go out, take up a sport.

"What's her goddamn problem?" Marcus said.

"Mister Metcalf?" said the intercom.

"Yes?"

"Principal Wafford would like to see you."

"I'll be right there."

Wonderful. Marcus commanded his feet not to shuffle like cow hooves outside the slaughterhouse. He waved at the secretary and knocked on the frame of the principal's posh office. Tom was watering the spider plants.

"Marcus. Come in, have a seat."

"What can I do for you?" Because that's the correct question. It will never be the other way around again. You are not my friend, and you never were.

"The spring talent show," Tom said, sitting.

"I'm sorry?"

"I need someone to organize it, script it, put it on." Tom smiled. He gestured fondly at Marcus. "You're the man for the job."

"Am I." 
"Yes. If you'd like."

This is a trap, said Marcus's mind. "Could I have a day to consider?"

"Certainly. Let me know tomorrow." They rose and shook hands. Marcus resisted the urge to grapple the principal's palm like a chicken neck. He left the office wondering why he didn’t simply refuse.

“The Check Engine light's on," Daisy said. She slammed the Dynasty shut, kicked her boots off, thundered into the house. She'd left her stage makeup on, a sign that practice had gone so badly she hadn't taken the time to scrub her face.

Marcus popped the hood and swam in the car's guts for a while, having not the slightest clue what the issue could be, his head indifferent to the task at hand, wandering instead to the talent show. He understood, after these few hours, why he hadn't refused. This was his chance. It was redemption staring him in the eye. He would do the talent show like a radio show, like Lake Woebegone. Expose Vanderbilt High to quality cultural programming, expand their feeble minds. He would write a sketch where he and the other teachers played characters from Star Trek: The Next Generation. He himself would play Captain Picard. He would intersperse the skits with Garrison Keillor-like commentary, which he himself would also read. He would call himself Karrison Geillor. It would be hilarious. Daisy would be in the bleachers, listening. She would watch as the lights came up and the student body leapt to its feet, hollered as one, in triumph, in adoration, for this humble man who lost his life's dream to a stranger from out of state, but gained instead another dream, teaching rowdy teenage rubes to love wholesome 
humor. Someone might secretly record it, pass it on to NPR. Garrison Keillor might be amused, might phone Marcus out of the blue and ask him to take a guest spot on the show. That guest spot would become a recurring role. He'd surpass Keillor in popularity, have his own show. He'd be an interviewee on All Things Considered, on which program, right now, the host questioned a FEMA officer about preparedness in the event of a terrorist attack. Marcus would meet such a man in the waiting room of NPR, as they each sat in preparation for their interviews. The man would ask what Marcus did for a living. "I have a radio show. It's nothing compared to your work." They would laugh. Marcus would be lying. It would be something, this radio show. This talent show, it would be everything.

"Marc? Supper."

"Right in." He saw the car's innards were a mess of odd, new disconnections. Like he'd randomly been tugging, twisting, and fraying the whole time he'd stood here.

They tried to talk him out of it. His fellow teachers, in rehearsals, reading their lines to Marcus's direction. They laughed, they were big Star Trek and Lake Woebegone fans, but they said to him, individually, in stolen moments - break room, hallway, staff meeting - "Marc, are you sure the kids will get this?"

'No, but that's the point. That's what will make it a transcendent experience for them. It will go beyond what they know. Trust me."

A good coach was, above all things, a man you could trust. And with only three weeks before the performance, he could brook no arguments, tolerate no doubters. Daisy 
heard through the high school grapevine that Marc was putting on the talent show. The two of them were barely talking, but she asked one afternoon as he drove her home - her car was still in the shop; whatever he'd done to the engine, the mechanics were having a hell of time fixing it - "Are you doing it like last year? The faculty band?" Several members of the teaching staff were fair to middling musicians. Last year they'd dressed up as The Grateful Dead. The students didn't know The Grateful Dead from Joyce's The Dead, but the band got a standing ovation.

"Nope," Marcus said. "You'll see."

She put her foot on the dash. "The play went fine. By the way."

"You start performances next week."

"We started performances last week. We finished Saturday."

Marcus never missed her onstage. "Why didn't you say something?"

'I did. You were busy writing. 'Scripting,' you said, 'I'm busy scripting, Daisy, not right now.' It's fine, it went fine. Don't sweat it."

He yammered apologies in excuses' clothing all the way back to the house.

"It's fine, Dad," she said when he parked. She shut the truck behind her and went inside.

With the Dynasty gone, Marcus had made space to set up the circular saw and the awl. He didn’t know what he was making yet, but he had six identical boards sanded smooth, eight thick lengths he'd rounded to table legs. He could make a table. He'd have to make two, he thought, tapping the garage button so it would shut. He'd have to make two tables, because he'd made eight legs. He began assembling the two tables but found himself, a minute later, shaping another leg on the awl. He found the sounds and motions 
soothing. He attended Daisy's play in his head, and she was wonderful. She had the lead role. She played every role, no howling dogs. She curtseyed for the audience and Marcus was front row center, and he threw her a football with roses sprouting out of its end. She went running for it, to a goal line at the rear of the stage. Daisy caught the ball, then it bounced out of her grip, but she dove for it, skidded, she catches it again! Where'd this kid come from?! From nowhere, John, from nowhere at all, but you've probably heard of her father, he's got a radio show.

Marcus spat a splinter of wood from the smile that bared all his teeth.

Years later, when Marcus was sleeping in a tiny horror show of a basement apartment, eating his dinners at a sports bar, playing trivia against two or three patrons with beer in their beards who were wondering - same as Marcus - what particular factor it was that had made their wives leave them; when he drove to his sister's in Colorado for Christmas because he had nowhere else to go, taking slick back-roads at eighty miles an hour in the hopes of crashing and dying of hypothermia, his head containing nothing but the hollow winds of acute despair and a working knowledge of winter car crash statistics; when, the following December, he auditioned for a local production of "A Christmas Carol" in order to have something to do, and he got the part of Scrooge, and learned his lines, and donned costumes, wore makeup, gesticulated, took suggestions from others as to how to improve, and improved; when he stood up in front of the audience that first night, a redeemed Ebenezer, and the crowd got to their feet applauding him, Marcus would finally understand that redemption had nothing to do with applause. 
Because the student body at Vanderbilt High didn't get it. They either didn't know who Karrison Geillor was referring to or they didn't care, or they figured - rightly - that if they did demonstrate knowing and caring, the majority would shun them. In high school, conformity wins. And if conformity dictates that one crumple the talent show program and throw it at the long table of teachers bent reading their scripts by lamplight as Garrison Keillor and his cohorts did during their live tapings - then the high schoolers, almost all fifteen-hundred of them, will crush their programs into tight paper balls and lob them out of the bleachers, across the gymnasium, pelting the faculty. And the faculty will read on, because a teacher must hold fast in the face of adolescent insult. They will read their parts as though - being adults - the soft projectiles thrown by adolescents do not sting. But they do. Had the adolescents thrown stones, their impacts could not have hurt more. And the faculty will hate the man who put them here. They will despise him. They will - being adults - forgive him, but they will not - being human - forget. And this will confirm, in the mind of the man who put them there, that the talent show was a trap set by the principal, who was not the man's friend.

It will rob the man of something precious. Or it will convince him it's time to sacrifice something precious at the altar of his disappointment.

Marcus thought it only fair that he clean up the paper. He didn't state this to anyone, in case they offered to help him. He went to the sound guys, who were concealed in a closet-like room off the gymnasium, and he asked inane questions about mics and speakers. He was hiding from his co-workers' condolences, but those weren't 
forthcoming anyway. The students grumbled out in a mass, the teachers escaped through side doors. The sound guys opted to wind cords tomorrow. They had to get home and study.

Marcus told the sound guys to leave the lights on, he'd get them. They waved, their caps askew and their shirts advertising concerts in jagged lettering. The gymnasium's neutral floors glowed, like an illuminated almond, but the floor was white and globular with packed paper. Like sugar on the almond.

Marcus got a garbage can from the corner, stooped, swept his arms wide and brought them together, grouping maybe two-dozen programs onto his forearms. He dropped them in the trash. He did this until his back was begging him to quit, then he straightened, stretched, did it some more.

He heard footsteps. Recognized them. The sound of them now was agony, but years later, he'd know their absence was the real agony. That if he heard them, he might not recognize them, might not know his daughter's quick feet, their pause to bend and pick up balled paper, their mince to the trash where he stood, his eyes shut, ashamed. Enraged at the shame.

"I'll get the paper," she said. "You handle the table and chairs, they're too heavy for me."

Marcus went to the chairs and folded them. He thought, My daughter's giving me orders and that isn't right. My daughter's surpassing me, he thought, and that's right, it's all right. He put the folded chairs on a rack that fit beneath the stage. The radio show hadn't used the stage. Maybe if they'd used the stage, then-. He folded the table. Daisy 
moved like a flamingo - awkward, not even a little graceful. He thought of needling her for that, then felt self-hate spill through his mind like an oil stain.

"I'll finish cleaning up," he said. "Why don't you head home, honey."

Daisy slapped her hands against her thighs to wipe them. "I'll tell Mom it went great."

"You don't have to. She won't ask."

Nearly the full length of the gym was between them, but the acoustics were such that a whisper would carry. That's why Marcus said the show should be in here. Their voices would carry, envelop the listeners. He hadn't thought how boos would carry. A side of Daisy's mouth lifted in a commiserating smile. 'I'm proud of you, Dad.”

Marcus would re-marry a woman plagued by insecurities even more debilitating than his, which would be the primary basis of his attraction to her. This woman would tell him how Marcus's daughters didn't appreciate him, didn't honor him, didn't love him, and the loop of these declarations would slather a thick layer of soil over the quicklime under which his love for his daughters lay buried. But they would rise as terrible, lurching monsters, as Daisy did the night he played Scrooge, as she did again when he heard she'd gotten married, again when she had her son. His wife would console him with quiet diatribes of vitriolic hate - bet the groom's a real prize, bet the kid's a real genius - and Marcus would say 'Now now' and laugh, relieved his wife had buried them again, where the ground roiled with their protests at this half-life in his head. He would mostly forget Daisy saying she was proud of him. He would mostly forget asking Daisy, "Why?" as he bent to pick up more programs. 
"Why?" she said, and scoffed. "It's my job."

Marcus squinted at her. "Well, you're fired."

Daisy stood still. She looked afraid. She looked young, but she wasn't. She was almost an adult.

"Go home,” Marcus said. "Get out of my sight."

On those rare instances he'd remember this exchange, Marcus would insist to himself she took it the wrong way. He'd shake his head and think: Oversensitive, just like her mother. But, years later, when he doffed his top hat on a stage not far from the sight of his disgrace, bowed low and felt a twinge in his back, he would scan the delighted faces in the audience, fail to find Daisy there, and know she was somewhere else, looking for a job as important as the one he'd fired her from.

He collected crumpled programs. He heard her soft steps. He looked up in time to see her disappear around a wall. There was the sound of a door closing.

Marcus took a break. He felt like he had forever, this was the last thing in his whole life he had to do. A quarter of a basketball court covered in crumpled talent show programs. He put his head in his hands, indulging the memory - just this once - of reading his favorite pun about a star date with the Borg, and the gentle pats of crinkled paper bouncing off his skull, arms, chest. Then he took the memory and pushed it to a corner where he'd keep it, with other secrets, unimagined secrets, the bricks and mortar of a life.

Marc stared fixedly at the stage, where he set her, gowned and garlanded, grown up and graceful. She was accepting an award. Her posture was humble and her voice subdued when she said her thanks. She didn't think she deserved it, whatever it was, but 
it was the highest honor her field could bestow. It was a lifetime of toiling toward the impossible, spurred on not by cheers of crowds, but by the lone, loud booing of her father that wouldn't let up, wouldn't abate.

The cheers tapered reluctantly. Daisy sang an aria, the notes as fine as warm rain. She should thank me, thought Marcus. She should thank me, but she never will. She'll succeed because she's encumbered by nothing. Thanks to torn-away roots, she'll travel to places I've never been. She won't have grounds for comparison to her success, so she'll curse me, despise me, when all I wanted was for her to be extraordinary. That's all right, Marcus thought as Daisy finished her song. She scanned the crowd for his face, but she couldn't see him.

That's all right, sweetheart, I forgive you. Now float away from me, darling. Sail away like a songbird. A storm.

A wave. 